\title{
Firing the Imagination Cremation in the Museum
}

\author{
Howard Williams
}

Williams, H. 2016. Firing the imagination: cremation in the modern museum, in H. Williams and M. Giles (eds) Archaeologists and the Dead: Mortuary Archaeology in Contemporary Society, Oxford: Oxford University Press, pp. 293-332.

\section{INTRODUCTION}

The displays of articulated, unburned, and fleshed human remains in European museums are often claimed to fixate and simultaneously repulse the modern viewer, and provoke all manner of varied responses in between these extremes (Brooks and Rumsey 2007: 279-80). Unused to the sights (and smells) of corpses and skeletons, the modern visitor is certainly fascinated by the uncanny nature of the archaeological dead. While bearing the signs of transformation by time and treatment, they often retain an unsettling individual persona, regularly enhanced by being posed, re-clothed, and sometimes awarded facial reconstructions when selected for museum display (Swain 2002, 2007a; Wallace 2005). Seemingly denying and disrupting the passage of time and drawing the past into the present, these cadavers afford the illusion of sleeping persons suspended between animation and oblivion (see also Nordström this volume). Such 'immortals' can become emblematic of entire societies and periods in the human past and icons of archaeology itself as a discipline that deals with the traces of human mortality through time (Nordström 2007, this volume; Williams 2009).

It is the strikingly 'human' and 'whole' cadavers that have provoked the strongest emotional responses from the public as well as securing direct spiritual connections for particular religious minority groups. Such is the case of the campaign by the British Order of Druids who focused their claim for reburial centred on the memorable and evocative skeleton of a Neolithic child 'Charlie' on display in the Keiller Museum at Avebury (see Giles and Williams this volume; Tatham this volume; Rathouse this volume). Such claims of affection and affinity are clearly predicated on the corporeal integrity and the emotive responses this integrity evokes for the viewer.

While human remains provoke the most powerful emotive engagements with the archaeological dead, other strategies for displaying mortuary contexts, such as casts of human bone (Goodnow 2006a: 18-19) and artist's reconstructions of funerals (Williams 2009; Giles this volume), can inspire strong reactions. The same also applies to dioramas with mannequins: their uncanny resemblances to living persons can create powerful imaginative and educational connections between visitors and past individuals and the societies they represent within the museum context. The Seven Vikings exhibition at the Moesgård Museum, for example, focused on the journeys of seven fictitious Viking Age individuals; they are encountered at the start of the gallery as seven sleeping (and some snoring) mannequins (Asingh 2011). In sleep, they appear living and dead, between past and present and hence disrupting history in a comparable way to a well-preserved skeleton or mummy. Hence, whether displays involve 'real' human remains, casts, mannequins, or simply images and photographs, the sense of the uncanny abject is 
sought in, and mediated through, visualized whole cadavers and reanimated figures inspired by inhumed skeletons in graves.

Resemblance to living people, or to be more accurate, just-dead persons, is what provokes the sense of abjection in the cadaver, not human remains per se (cf. Goodnow 2006b). This seems married to a discourse that regards the cadaver as 'evidential', projecting the past simply through the disclosed information contained in or exhibited from graves and other mortuary contexts (Crossland 2009a). Many exhibitions focusing on mortuary data emphasize the scientific information that dead bodies reveal, and even attempt to reconstruct the process of excavation, through articulated and fleshed human remains and the stories of past lives, diseases, and circumstances of death they show (see Williams 2009). As 'evidence', intact cadavers are thus portrayed as windows onto past lived experiences of being human. Good examples are the London Bodies and Skeletons: London's Buried Past exhibitions (Werner 1998; Redfern and Bekvalac 2013). Hence, this evidential approach, predicated on an abject status created by the archaeological cadaver's similarity to a once-living person, makes the intact or represented cadaver a powerful educational and memorable dimension of many Western museums. Inversely, this discourse of reconstruction, focusing on identities rehabilitated and created through burial archaeology and bioarchaeological investigation and resulting in museum displays, finds a parallel with the perceived creation of corporeal and community wholeness and healing achieved through the process of repatriating and reburying human remains from museums (see McClelland and Cerezo-Román this volume).

Simultaneously and significantly for this study, this fixation with visually and materially resurrecting a corporeal integrity for the dead reflects the long established ambivalence in Western tradition towards the disarticulation and fragmentation of the corpse. It also reflects the commodification of the body as an entity, readily objectified as a substance to be treated and traded and consumed as image and art (Brooks and Rumsey 2007; Crossland 200gb).

Indeed, many mortuary archaeologists who regard their task to be the empirical resurrection of past lives and mortuary behaviour have garnered an intellectual ambivalence to past mortuary practices that involve the dissolution or transformation of the cadaver. Such practices are often characterized as exotic, facilitating interpretation only via far-flung corners of the world. Alternatively, they are seen as barriers to interpretation and practices that must be overcome rather than studied in their own right. From this perspective, archaeologists seem to share with neo-Pagan and Judaeo-Christian groups a tendency to valorize corporeal integrity and promoting affinities with 'whole' bodies indexically linked to past 'individuals'. The flip-side of this approach is that both draw upon a post-Reformation discourse that mirrors Sir Thomas Browne's Urne Buriall (1658) in which cremation is regarded as oblivion and illustrates with material clarity that: 'there is no antidote against the Opium of time ...' (Browne 1658: 74).

Thus, cremated and other fragmentary human remains are often regarded in contemporary society as both less 'evidential' and less 'abject', albeit to varying degrees by different researchers. This has ramifications for how museums display the dead. Alongside other categories of disarticulated and fragmentary human remains in museums, cremains are 
often implicitly perceived to be second-rate data and second-rate ancestors, more intractable as objects of scientific scrutiny, less knowable, less human, and less individual as persons.

It is difficult to escape the evidential role of the unburned body in forensic investigations, for example, as witnesses of the genocide of thousands upon thousands by the Khmer Rouge and counter to the country's Buddhist cremating traditions (Cougill 2006). Yet equally to regard cremation as non-evidence has powerful and disturbing ramifications, which, if taken to extremes, implies that those whose bodies are subject to cremation, from murder victims to victims of the Holocaust, are denied an historical identity and corporeality. The destructive force of cremation on the identification of whole individuals should not be uncritically translated and equated with a reduced historical and cultural value. Therefore, it is revealing that museums seem rarely to receive objections to the display of cremated human remains which are rarely afforded centre-stage in displays in a manner comparable to the Egyptian cadaver 'Ginger' or the Lindow Man at the British Museum (but there are exceptions, see Sayer this volume).

Hence, I suggest that both academic and popular cultures persist in regarding disarticulated human remains as less worthy of affording narratives and identities and less valuable for archaeological research. Indeed, the same stark avoidance of cremation applies to popular syntheses on mortuary archaeology in which cremation rarely receives more than passing attention (e.g. Bahn 2002; Chamberlain and Parker Pearson 2001; Parker Pearson 1999). More surprising still, in discussions about how the dead are displayed in museums, remation has been completely overlooked in favour of mummies of different kinds and unburned skeletons (e.g. Beattie 1999; Swain 2002, 2006, 2007a; Curtis 2003; Goodnow 2006b; Brooks and Rumsey 2007; Giles 2009; Sanders 2009; Jenkins 2010; Sayer 2010; Hall 2013). Therefore, in combination, articulated cadavers in museology and mortuary archaeology are part of a wider valorization of corporeal integrity that equates to both scientific data and human likeness. Only in extreme examples, where affinities of place and cultural identity outweigh all other considerations, do we find cremation being the focus of present-day disputes. For example, the recent disruption and calls for reburial of the cremation burials re-excavated at Stonehenge relates to the specific affinities with that iconic ancient monument by a range of neo-Pagan groups (Parker Pearson et al. 2013). The same applies to the repatriation of Aboriginal cremains to Australia (Swain 2007b: 193). These instances aside, the pervasive representational bias means that anyone reading the recent literature on mortuary archaeology and observing displays of the dead in museums might be forgiven for thinking that archaeologists rarely investigate cremating societies, that cremated human material is rarely placed on display, and more seldom still does cremation inspire popular interest and public displays of emotion and affinity. Indeed, a number of recent books dealing with the socio-political context of mortuary archaeology do not even deem cremation to be worthy of listing in the index let alone discussion (e.g. Giesen 2013).

Of course, it is true that cremating human remains results in the fiery fragmentation, distortion, and shrinkage of human bone and hence obscures both scientific data and the human likeness. Yet cremation operates in past and present in different ways to those foregrounded in the recent academic and public emphasis on corporeal wholeness and 
individuality in death. Since the Renaissance in Europe, cremation has been frequently encountered in the archaeological record, as have other strategies for transforming and disarticulating the cadaver after death. Moreover, over the last half century, macroscopic and microscopic osteological and archaeological analyses of cremation repeatedly challenge the view that cremation is second-rate data (Williams 2008). In terms of the popular imagination and global heritage, cremation enters into the interpretation of many iconic sites of prehistoric and early historic data from ancient Greece to the Viking world. Regarding heritage sites, we can readily encounter many thousands of memorials covering cremation graves, from the Aubrey Holes that form a key element of the narrative of Stonehenge to the vast Romano-British burial mounds known as the Bartlow Hills of Essex. One can walk past monuments covering the cremated dead at the famous Isola Sacra cemetery of Ostia, Italy (Hope 1997a), and tourists can walk around the hundreds of burial mounds, many covering the cremation graves of the former occupants of the Viking town of Birka, Sweden (Gräslund 1981). Indeed, architectures and landscapes of cremation in the modern era, such as Golders Green crematorium, London, and the Stockholm South Cemetery, are themselves international heritage destinations (Williams 2011). The cremated dead also continue to connect to archaeological sites: frequently modern ashes are scattered at beauty spots including ancient monuments, thus allowing the intangible dead to diffuse into tangible and memorable places for the individual, their family, and friends. The archaeology and literature of cremation, as for example described in ancient Roman texts and revealed by Roman tombs, has inspired literature, and the repeated reimagining of mythical, legendary, and prehistoric and early historic pasts. Such imaginings even inspire the memorials, architectures, and landscapes of crematoria in the modern era (Back Danielsson 2011). Hence, cremation's omission from discussions of the impact and engagement of mortuary archaeology with contemporary society is both problematic and revealing; consequently it demands closer scrutiny.

Against this background, it seems inherently problematic to isolate and talk about a universal category of 'human remains' on display with which the viewing public can engage. Instead, modern museums construct varied and complex identities—both individual inhering within single skeletons and dividual distributed between bones and material cultures-as well as sophisticated narratives involving different categories of human remains: articulated, disarticulated, and frequently without deploying any human remains at all. Via these display strategies, different senses of past societies, personhoods, and contrasting emotive immediacies are constructed and arranged for the modern public. Indeed, this mirrors a broader and complex, cenotaphic commemorative culture of late twentieth- and early twenty-first-century Britain in which popular deathways involve multiple locales, memorials, and material cultures where the body is implied, absent, or elsewhere. Cremation needs to be considered as part of this variability in the museum reanimation of the ancient dead through display, and the focus on whole articulated human remains both patronizes visitors and presumes that their only potential appreciation of life and death in the human past is through the individual body.

This chapter uses four case studies to rectify this scholarly discrepancy and illustrate the wide variety of ways in which cremation is displayed within the museum environment but is rarely subject to critical discussion. For the sake of brevity, other heritage locales are not considered in this chapter. The wider potential of this study is to expand and enrich the 
study of the display of human remains and provide a new platform from which to consider the ethical, political, and sociological dimensions of the archaeological engagement with mortality in contemporary society. In particular, I hope to illustrate how fragmentary, disarticulated, and fire-transformed cadavers provide versatile and contrasting corporealities within museum displays, often juxtaposed alongside articulated and fleshed cadavers to create contrasting identities for the ancient dead within modern society (see also Williams 2009). However, my aim is not to herald 'good practice' or deride 'bad practice', since all current strategies of display are currently contributing to current understandings of cremation and the cremated dead in contemporary society.

\section{A TYPOLOGY OF CREMATION ON DISPLAY}

The first step in exploring cremation on display in the modern museum is to create a basic typology of the remains encountered that present the cremated dead. Based on museum visits over the last decade in Scandinavia, the UK, and Republic of Ireland, I propose ten broad and frequently combined categories currently in operation to display the cremated dead directly or indirectly (Table 14.1):

1. Texts and audio commentaries: usually they provide few details and simple descriptions of what past cremation practices comprised;

2. Artefacts and vessels derived from cremation graves are often displayed, whether their original context is discussed or implied in their arrangement or not;

3. Memorials and monuments associated with the cremated dead can be displayed, with or without explicit associations with cremation;

4. Cremated bone is itself displayed in a manner comparable to artefacts and substances or arranged into 'deposits' and containers;

5. A widespread practice is to mock-up associations between artefacts;

1. ashes, and urns as an assemblage, giving the viewer a sense of what cremation graves from particular periods and regions looked like;

6. Reconstructions of the grave-contexts themselves can be recreated, in which cases the context as well as the assemblage is afforded attention;

7. Architectures, monuments, wider cemetery environments, and landscape settings associated with cremation can sometimes be displayed;

8. Excavation records, including plans, sections, and photographs, can be employed to communicate cremation practices and burials;

9. Artists' impressions and models can be employed to bring cremation ceremonies 'to life'

10. Historical, literary, and sometimes even ethnographic accounts might be drawn upon through text and image to 'flesh out' the archaeological evidence.

For simplicity, this discussion will not address other important ways in which ancient cremation practices revealed by archaeology are made manifest in popular culture. For example, I leave for others to discuss open-air re-enactments of cremation funerals, and the cemeteries and monuments associated with cremation surviving the modern cultural landscape, focusing simply on the ten principal ways by which cremation is materialized within the museum and heritage centres. Equally, for sake of simplicity, I focus on a series of permanent physical exhibitions rather than temporary exhibitions and online media. This 
focus allows us to compare museums of different scale and character to identify both shared themes and subtle variations in how cremation is displayed.

\section{HJEMSTED OLDTIDSPARKEN-AN OPEN-AIR MUSEUM}

The first museum case study is Hjemsted Oldtidsparken (HO) in southern Jutland, Denmark (Table 14.2).1 Opened in 1996 as an open-air country park as much as a museum, $\mathrm{HO}$ presents archaeology found around Hjemsted through large-scale excavations and dating mainly to the pre-Roman Iron Age, Roman Iron Age, and Migration Period (later first millennium $B C$ and early first millennium $A D$ ). I visited in 2010 while participating in the fieldtrip associated with the Internationales Sachsenposion conference in Haderslev. The museum is divided into two zones. First, the large open-air museum with numerous reconstructed Iron Age dwellings focuses attention upon daily life in the Iron Age. Second and in stark contrast, the subterranean museum aptly considers death and burial in the Iron Age, reflecting the well-preserved Iron Age cemeteries revealed at the site (Ethelberg 1986, 1990).

Table 14.1 Broad categories identified in the display of the cremated dead in museums

\begin{tabular}{|l|l|}
\hline Code & Type \\
\hline 1 & Text and Audio \\
\hline 2 & Artefacts and Materials \\
\hline 3 & Memorials and Monuments \\
\hline 4 & Bones \\
\hline 5 & Assemblages \\
\hline 6 & Contexts \\
\hline 7 & Architectures and Landscapes \\
\hline 8 & Excavation Records \\
\hline 9 & Artist's Impressions and Models \\
\hline 10 & Historical, Literary and Ethnographic references \\
\hline
\end{tabular}


Table 14.2 Key displays of cremation at $\mathrm{HO}$ witnessed in 2010

\begin{tabular}{|c|c|c|}
\hline Cabinet & Type & Description \\
\hline \multirow{2}{*}{$\begin{array}{l}\text { HO1 - Bronze Age } \\
\text { Cremations }\end{array}$} & 1 & Text panel introducing the material. \\
\hline & 4 & Bones displayed in triangular arrangement on shelf within display case \\
\hline \multirow[t]{4}{*}{$\begin{array}{l}\text { HO2 - Burial Customs 500- } \\
50 \mathrm{BC}\end{array}$} & 1 & $\begin{array}{l}\text { Text panel outlining that large cemeteries are the norm and burial location was static. } \\
\text { There are no big differences in burial wealth indicative of social stratification, it says }\end{array}$ \\
\hline & 2 & Artefacts displayed, including cinerary urns. \\
\hline & 8 & Photographs of burials under excavation \\
\hline & 9 & $\begin{array}{l}\text { Isometric plan of a cemetery, half under turf,illustrating the character of the , half post- } \\
\text { excavation revealing the character of the archaeological traces. }\end{array}$ \\
\hline \multirow[t]{2}{*}{$\begin{array}{l}\text { HO3 - New Burial Customs, } \\
50 \mathrm{BC}-1 \mathrm{BC}\end{array}$} & 1 & $\begin{array}{l}\text { Explains that these graves show greater wealth and variation and family plots replace } \\
\text { large cemeteries suggesting increasing social hierarchy. }\end{array}$ \\
\hline & 5 & A partial cinerary urn containing cremains and a bronze brooch. \\
\hline \multirow{2}{*}{$\begin{array}{l}\text { HO4 - Roman Iron Age } \\
\text { Weapon Burials }\end{array}$} & 1 & Text panel introducing the material \\
\hline & 5 & $\begin{array}{l}\text { Cinerary urns containing cremations within display case of martial implements found in } \\
\text { Roman Iron Age graves. The artefacts are displayed as assmeblages separate from the } \\
\text { urns containing cremains. }\end{array}$ \\
\hline \multirow{2}{*}{$\begin{array}{l}\text { HO5 - Roman Iron Age } \\
\text { cremation cemetery }\end{array}$} & 1 & Text panel introducing the material \\
\hline & 7 & $\begin{array}{l}\text { Visitors walk over both cremation and inhumation graves visible beneath their feet. } \\
\text { Cinerary urns contain cremains and artefacts. }\end{array}$ \\
\hline \multirow{3}{*}{$\begin{array}{l}\text { HO6 - Peasants' graves - } \\
\text { AD 1-200 }\end{array}$} & 1 & A description of the artefacts found in male and female cremation graves. \\
\hline & 2 & $\begin{array}{l}\text { No cremains in this display, only the urns. Artefacts are displayed separately but by } \\
\text { context on near-vertical triangular boards. }\end{array}$ \\
\hline & 8 & $\begin{array}{l}\text { Photographs of the two urns in section are adjacent to the text panel together with a plan } \\
\text { of the graves' location on the site plan. }\end{array}$ \\
\hline \multirow[t]{2}{*}{$\begin{array}{l}\text { HO7 - A Puzzle of Bone } \\
\text { Fragments }\end{array}$} & 1 & $\begin{array}{l}\text { Explains the effect of cremation on the human skeleton and its preservation and the } \\
\text { subsequent problems of identification by specialists. }\end{array}$ \\
\hline & 4 & $\begin{array}{l}\text { Vertical white-on-black outline of human skeleton, upon which fragments of cremated } \\
\text { bone have been placed at the correct anatomical position. }\end{array}$ \\
\hline \multirow{2}{*}{$\begin{array}{l}\text { HO8 - A Burial Ground at } \\
\text { Hjemsted }\end{array}$} & 1 & Text panel introducing the material \\
\hline & 8 & A cemetery plan is annotated with photographs of each grave taken during excavation. \\
\hline
\end{tabular}

I begin with $\mathrm{HO}$ because it is a museum that uses many strategies for displaying the dead retrieved from a well-preserved Iron Age archaeological landscape that has received extensive investigation by modern archaeological methods. This is a striking piece of bespoke architecture, and there is plenty of space for innovative strategies for communicating the archaeological past to visitors. Hence, the manner in which cremation is displayed is not overly restricted by attempts to fill a pre-existing space. Furthermore, the 
juxtaposition of an above-ground open-air museum and underground museum emphasizes how the division between 'living in the past' and 'death in the past' fossilizes a major division in how the past is presented in the modern museum. Open-air museums often emphasize daily life through re-creation, forming a timeless world in which death is denied. The only above-ground indication of mortuary activity is in the car park where the visitor is greeted by an ancient burial mound topped by three giant spears. In contrast, the traditional museum is designed to appear static, still, and almost as if the dead are in suspended animation. Hence, the traditional museum is still recognized as an appropriate venue for the solemn vestiges of ancient obsequies.

Within the subterranean museum at $\mathrm{HO}$, we find text panels describing cremation but also artefacts from inhumation and cremation graves displayed for their own purposes and divested of context. The inhumed cadaver is displayed via mannequins within mock-up graves and displays of Iron Age costume. Yet equally, we find a diversity of ways by which the cremated dead are displayed. Artefacts and piles of cremated bone ( $\left.\mathrm{HO}_{1}\right)$ occur as do conventional displays of cremains within cinerary urns ( $\mathrm{HO}_{2}, \mathrm{HO}_{3}$, and $\mathrm{HO}_{4}$ : Fig. 14.1). Archaeological plans (e.g. $\mathrm{HO} 8$ ) and plenty of site photographs (e.g. $\mathrm{HO}_{2}$ and $\mathrm{HO} 8$ ) illustrate discoveries of cremation graves on the site, while the impact of cremation on anatomy is revealed through burned human remains situated upon a vertical outline of a human skeleton ( $\mathrm{HO}_{7}$ : Fig. 14.2). The display of numerous urns and artefacts afford a sense of mortuary variability within the same population ( $\mathrm{HO}_{5}$ and $\mathrm{HO}_{6}$ ). Yet the most striking of all is a reconstruction within the floor of the museum of an entire burial ground, including cremation and inhumation graves, their spatial relationships mirroring their distance from each other as revealed during excavation ( $\mathrm{HO}_{5}$ : Fig. 14.3).

What is apparent is the ability of the cremated dead within $\mathrm{HO}$ to take on numerous guises and populate the museum space within conventional display cabinets. Equally significant is how cremation and inhumation graves spread out into the visitor's space, mimicking, and perhaps provoking reflection upon, the many ways in which the dead would have been handled in the past. What is not displayed is equally palpable: neither is there a reconstruction of a cremation ceremony nor any attention to the mortuary process, dimensions so important for understanding Iron Age cremation practices in Scandinavia (e.g. Høilund Nielsen 2009). Moreover, despite the rich strategies of display, how cremation took place and why it varied is left to the visitor's imagination. 


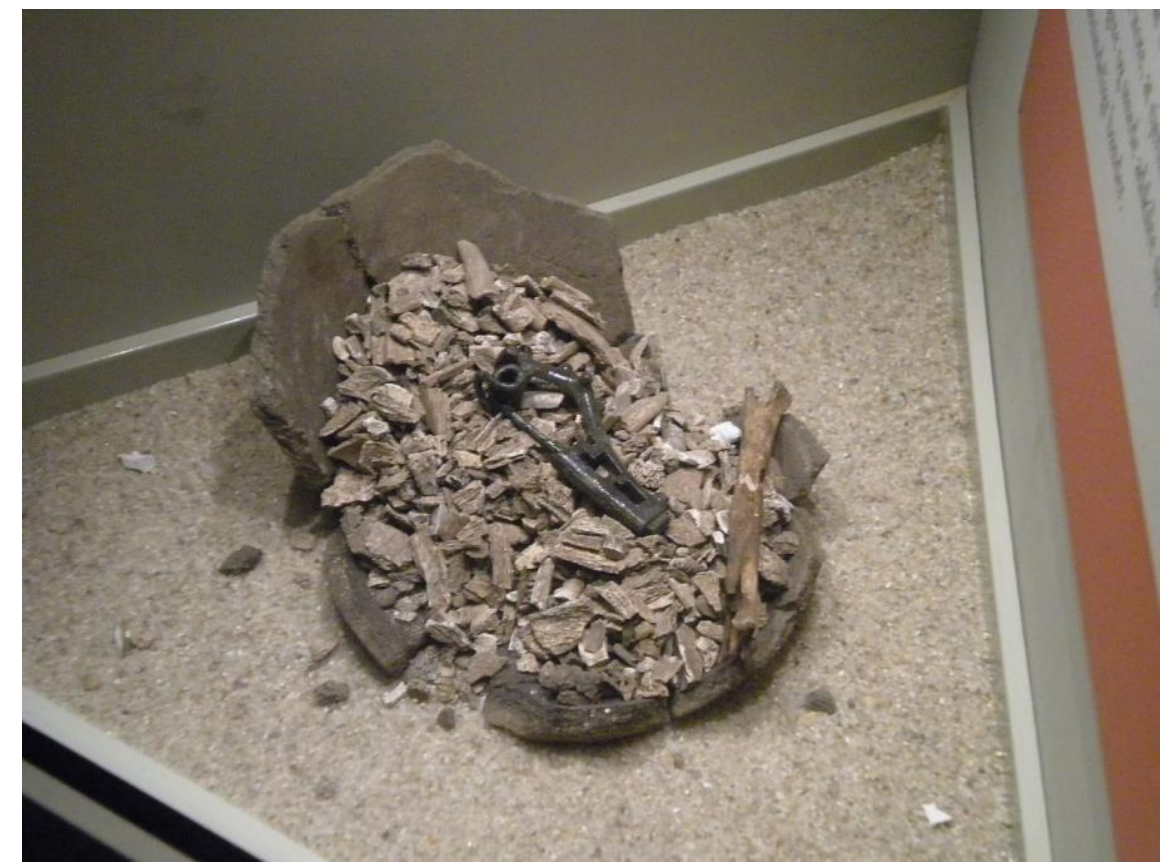

Fig. 14.1 Cremated human bone arranged in fragmentary urn with artefacts, HO (Photograph by Howard Williams, 2010)

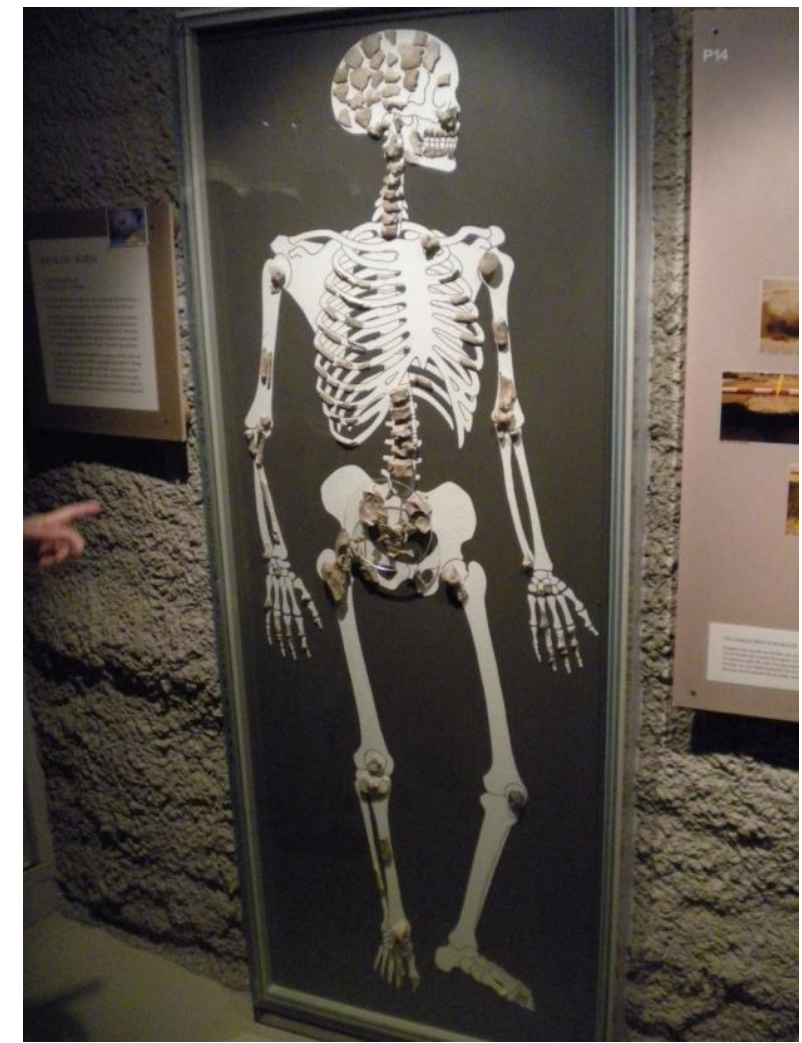

Fig. 14.2 Cremated human remains placed upon an outline of a human skeleton, $\mathrm{HO}$ (Photograph by Howard Williams, 2010) 


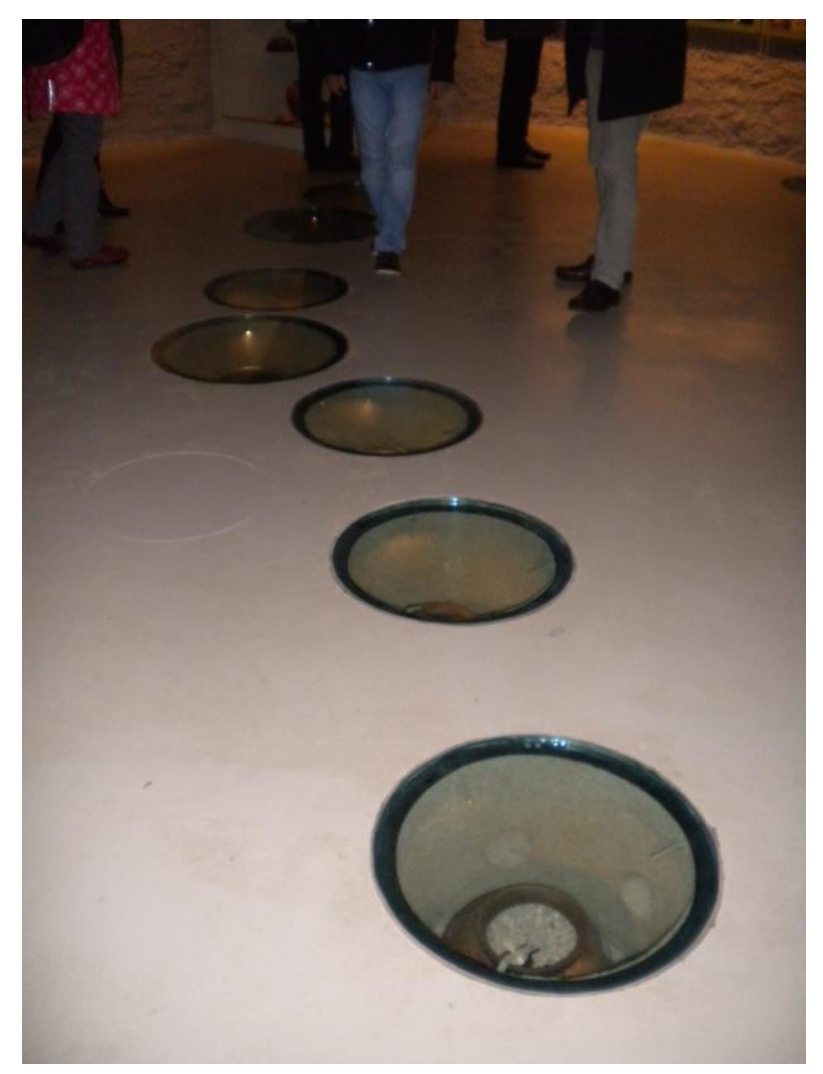

Fig. 14.3 Arrangement of Iron Age cinerary urns within the floor of the museum mimicking their spatial arrangement upon excavation, $\mathrm{HO}$ (Photograph by Howard Williams, 2010)

\section{COLCHESTER CASTLE MUSEUM-A TOWN MUSEUM}

Visited in 2012 and housed within a Norman keep, Colchester Castle Museum, Colchester, Essex, UK (hereafter CM), provides our case study of a museum in which the dead are widely deployed to narrate the history of a town and its immediate environs (Table 14.3; see Anon 1997 and Crummy 1997). In contrast to HO, the displays enjoy a generous space but are restricted by the pressures of a pre-existing historic environment. Moreover, in contrast to $\mathrm{HO}$, many of the finds result from nineteenth-centuries discoveries, with many of them lacking a well-recorded context. The displays have run for over two decades.

The phenomenal range of guises by which the ancient dead are displayed within the town museum at $\mathrm{CM}$ is striking and comparable to HO. A map of Roman cemeteries around Colchester, Roman tombs, and four displays of unburned human remains were found: (i) 'Bones from Balkerne Hill' associated with the Roman invasion, (ii) 'Aches and Pains': bones displaying Roman-period diseases and medical practices, (iii) 'The Art of Death' featuring three lead coffins, photographs of their contents, and associated artefacts, and (iv) two late Romano-British 'Christian' inhumation graves from the Butt Road cemetery.

Other periods are narrated through unburned human remains. A piece of skin found under a door hinge of Copford Church is displayed, possibly providing tangible evidence somehow linked to the local folklore that the skins of Danes were pinned to church doors as deterrents. To these, we might add memorial traces of the dead: near the entrance is a 
commemorative plaque to the Quaker, James Parnell, who was imprisoned for his faith and died in Colchester Castle in 1696, aged 19.

Table 14.3 Key displays of cremation at CM witnessed in 2012

\begin{tabular}{|c|c|c|}
\hline Cabinet & Type & Description \\
\hline $\begin{array}{l}\text { CM1 } \\
\text { Colchester Vase }\end{array}$ & 5 & $\begin{array}{l}\text { Famous icon of the museum and Colchester, displayed in a wall-safe near the entrance to the } \\
\text { museum. }\end{array}$ \\
\hline \multirow{4}{*}{$\begin{array}{l}\text { CM2 } \\
\text { Bronze Age - 'Death and } \\
\text { Burial' }\end{array}$} & 1 & $\begin{array}{l}\text { Text accompanying art and artefacts explains briefly the prevalence and characteristics of } \\
\text { Bronze Age cremation practices, } 2000-1000 \mathrm{BC} \text {. }\end{array}$ \\
\hline & 1,9 & Jupes Hill barrow with a secondary cremation burial within the ditch. \\
\hline & $1,2,5$ & $\begin{array}{l}\text { Two collared urns on a mock-ground-surface of pebbles to invoke the context of discovery. } \\
\text { One was found upside down placed over cremated remains of a girl, but these remains are not } \\
\text { displayed. The second collared urn contained cremated bones, found near the Jupes Hill } \\
\text { barrow. }\end{array}$ \\
\hline & $1,2,4$ & $\begin{array}{l}\text { Deverel-Rimbury cinerary urns also displayed in a comparable way in two glass cabinets. } \\
\text { Cremated bone displayed adjacent to these urns. }\end{array}$ \\
\hline CM3 & 1,2 & Five 'Belgic' vessels ( $50 \mathrm{BC}$ to $\mathrm{AD} 43$ ) are presumably all from cremation graves. \\
\hline $\begin{array}{l}\text { CM4 } \\
\text { Lexden Tumulus }\end{array}$ & $1,2,3$ & $\begin{array}{l}\text { The famous Lexden Tumulus is displayed, the text panel explaining that they contained the } \\
\text { 'cremated remains of an important man (possibly a king of the Trinovantes called } \\
\text { Athedomarros)' and the artefacts were broken as part of the funeral ritual and the grave } \\
\text { desecrated not long after their burial. }\end{array}$ \\
\hline $\begin{array}{l}\text { CM5 } \\
\text { Colchester Child's Grave }\end{array}$ & $1,2,8$ & Rich display of artefacts from the grave with antiquarian illustration of the assemblage. \\
\hline $\begin{array}{l}\text { CM6 } \\
\text { Stanway 'warrior burial'. }\end{array}$ & 1,2 & Artefacts displayed derive from a 'native style cremation burial'. \\
\hline CM7 & 3 & Tombstone of Longinus Sdapeze, son of Matygus \\
\hline Roman tombstones & 1,5 & $\begin{array}{l}\text { Tombstone of Marcus Favonius Facilis. An early Roman tombstone juxtaposed with lead } \\
\text { canister, glass bottle and copper-alloy bowl in cabinet with pebble-mock ground-surface. }\end{array}$ \\
\hline CM8 & $1,2,5$ & 'Storage bottle re-used to hold cremated human bones AD 75-200' \\
\hline CM9 & 1 & $\begin{array}{l}\text { Text panels sometimes state that the pots now still hold cremated remains but they are } \\
\text { concealed from view. }\end{array}$ \\
\hline
\end{tabular}




\begin{tabular}{|l|l|l|}
\hline Columbarium & 6 & $\begin{array}{l}\text { A variety of different kinds of Romano-British cremation burial found from in and around } \\
\text { Colchester, many placed on pebble mock ground surface. }\end{array}$ \\
\cline { 2 - 3 } & 7 & $\begin{array}{l}\text { The choice of a wall-display alludes to the Roman-style of columbarium tomb, unknown } \\
\text { from Colchester but known from Italy. }\end{array}$ \\
\cline { 2 - 3 } Mersea Island & 5 & $\begin{array}{l}\text { Above the columbarium, a painted landscape scene of Roman cemetery and procession on } \\
\text { road. }\end{array}$ \\
\cline { 2 - 3 } & 7,8 & From the Mersea Barrow, a glass bowl holding the cremated remains of a child. \\
\cline { 2 - 3 } & 4,5 & $\begin{array}{l}\text { Photographs of the site during excavation and in recent times. Diagrammatic section through } \\
\text { the grave, from the original excavation report. }\end{array}$ \\
\cline { 2 - 3 } & $\begin{array}{l}\text { Second-century cremation group from Mersea Island in a glass vessel with lead plate as a lid. } \\
\text { Test-tube containing cremated bone upon cremated bone. }\end{array}$ \\
\hline
\end{tabular}

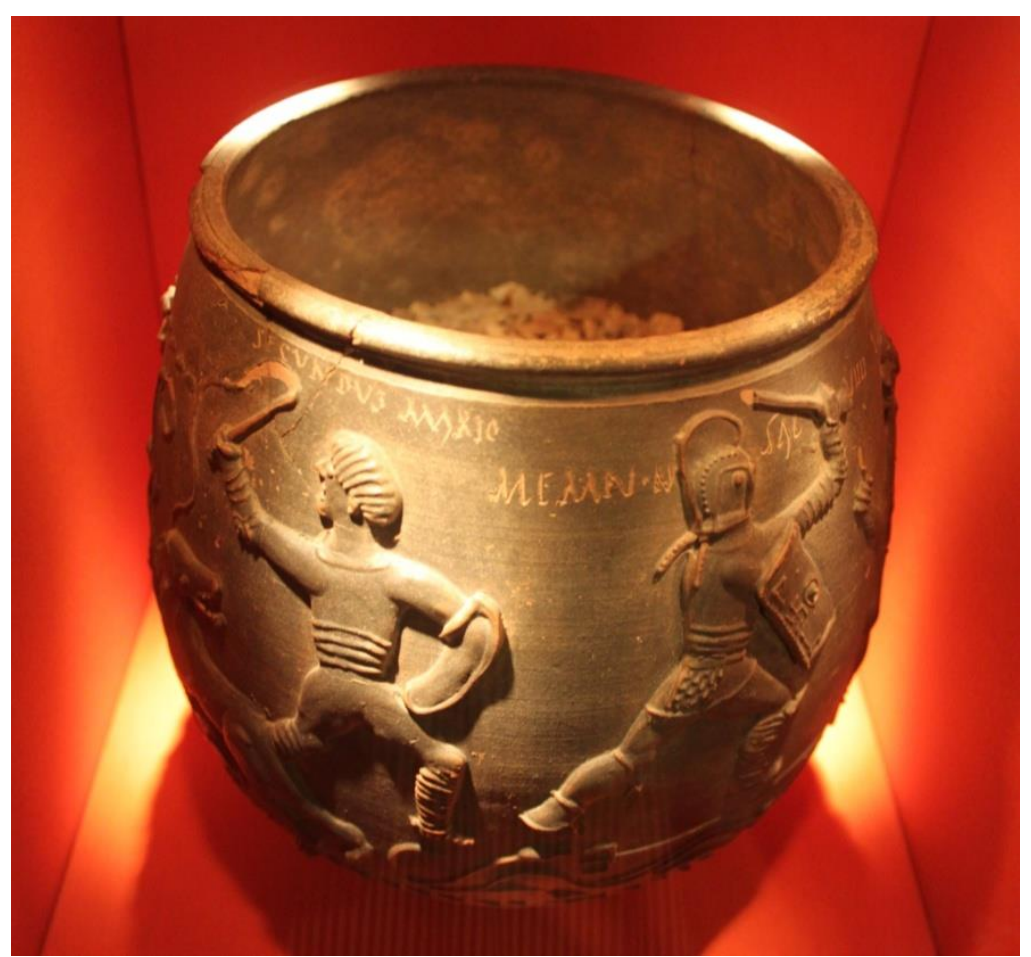

Fig. 14.4 The Colchester Vase, still containing cremated human remains but difficult for the visitor to spot within its wall-safe, CM (Photograph by Howard Williams, 2012) 


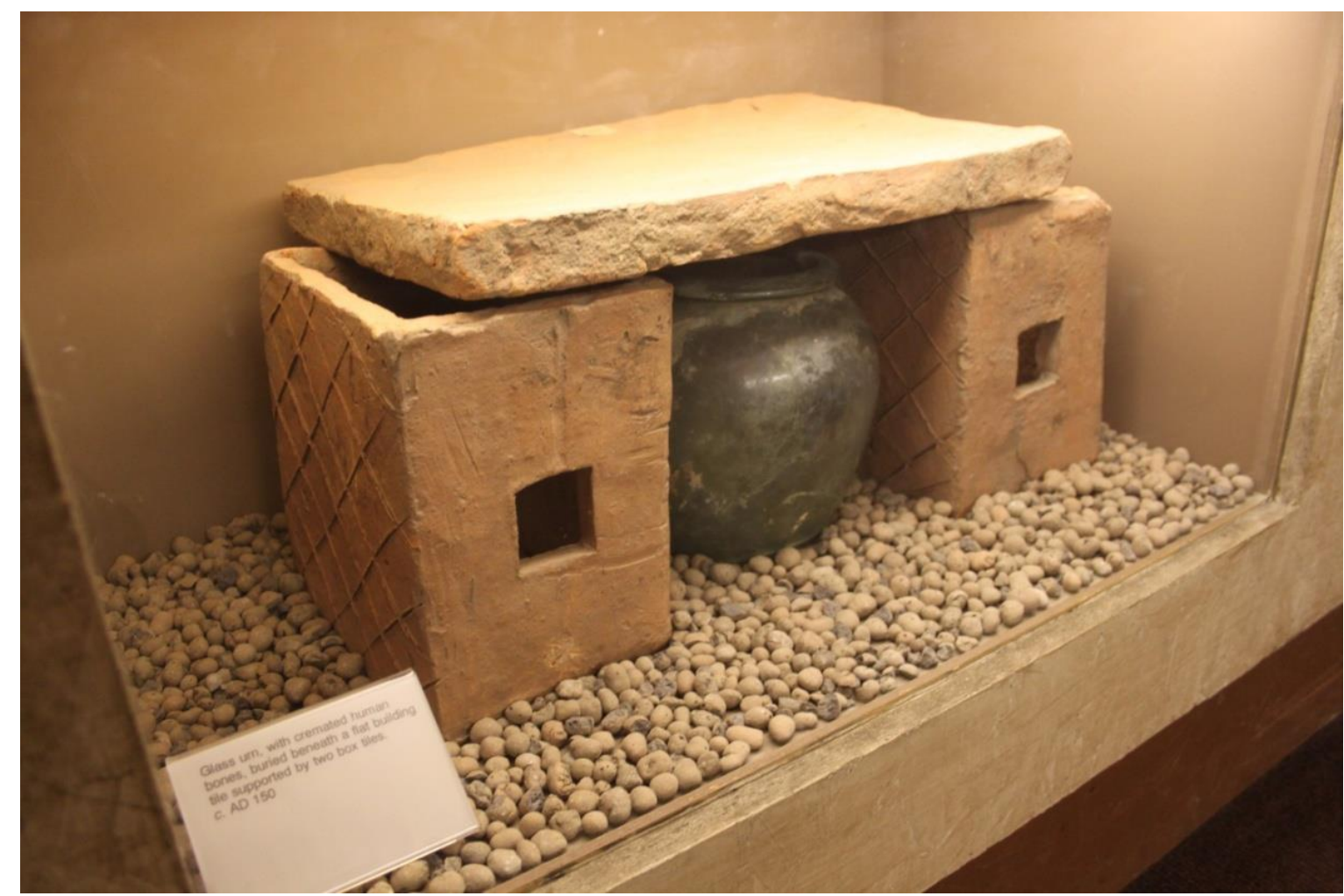

Fig. 14.5 Mock-up of Romano-British cremation burial, part of the 'columbarium' at CM (Photograph by Howard Williams, 2012)

Yet, cremated human remains are ubiquitous and the variability is illustrated by discussing ten displays relating to three eras: the Bronze Age, the late Iron Age, and the RomanoBritish period. Further examples are excluded from this study: including the burned (not necessarily cremated) human jaw associated with the Boudiccan sacking of the city.

Within this variability, text is the most common medium, usually taking a brief, descriptive approach to mortuary procedures. Yet artefacts often stand for cremated remains that are not available or chosen for display $\left(\mathrm{CM}_{3}, \mathrm{CM}_{5}-7\right)$ or are obscured by the presence of artefacts and cinerary urns themselves ( $\mathrm{CM} 7, \mathrm{CM} 9)$. This latter scenario is true of the famous and iconic Colchester Vase with its gladiatorial scenes (Fig. 14.4). Displayed in a wall-safe by the entrance as an artefact, only with the information provided by the curator could I (being slightly below average height for a UK male) readily apprehend that, from a certain angle, it is possible to view cremated human remains that have been kept within this vessel since its discovery in the nineteenth century $\left(\mathrm{CM}_{1}\right)$. In other cases at $\mathrm{CM}_{\text {, the }}$ cremains and artefacts are displayed in mock-ups of their original arrangement in the grave (Fig. 14.5). In one example, cremains in a glass vessel illustrate the many uses of glass in Romano-British society (CM8). Ashes can be displayed separately (CM2) and in one case within the antique test-tubes in which they were stored following excavation in the $1920 \mathrm{~s}$ and thus implying something-unexplained-about the history of archaeology $\left(\mathrm{CM}_{4}\right.$, Fig. 14.6. There are numerous examples of cremains within vessels ( $\left.\mathrm{CM}_{1}, \mathrm{CM}_{2}, \mathrm{CM}_{7}-10\right)$ and within mock-archaeological contexts (CMg). The combination of an assemblage comprising the cinerary urn and a Roman tombstone of Marcus Favonius Facilis (RIB 200) is a rare and striking juxtaposition of above- and below-ground archaeology coalescing within a 
museum display of a cremation grave (Fig. 14.7). This allows the visitor to simultaneously gaze at his memorial inscription and portrait and then imagine the hidden contents of his urn: a unique instance of a cremated individual's portrait, without visible human remains, in a fashion that allows his known identity to fully communicate to the visitor ( $\mathrm{CM}_{7}$; see Hope 1997b: Plate XVI). Meanwhile, another striking success of the CM exhibition of the RomanoBritish dead is a 'columbarium' - a wall of death-with the mock-up arrangement of cremation graves of different sizes and utilizing different grave structures and grave-goods, thus providing a sense of the rich mortuary variability in Romano-British cremation practices within the same display (Fig. 14.5).

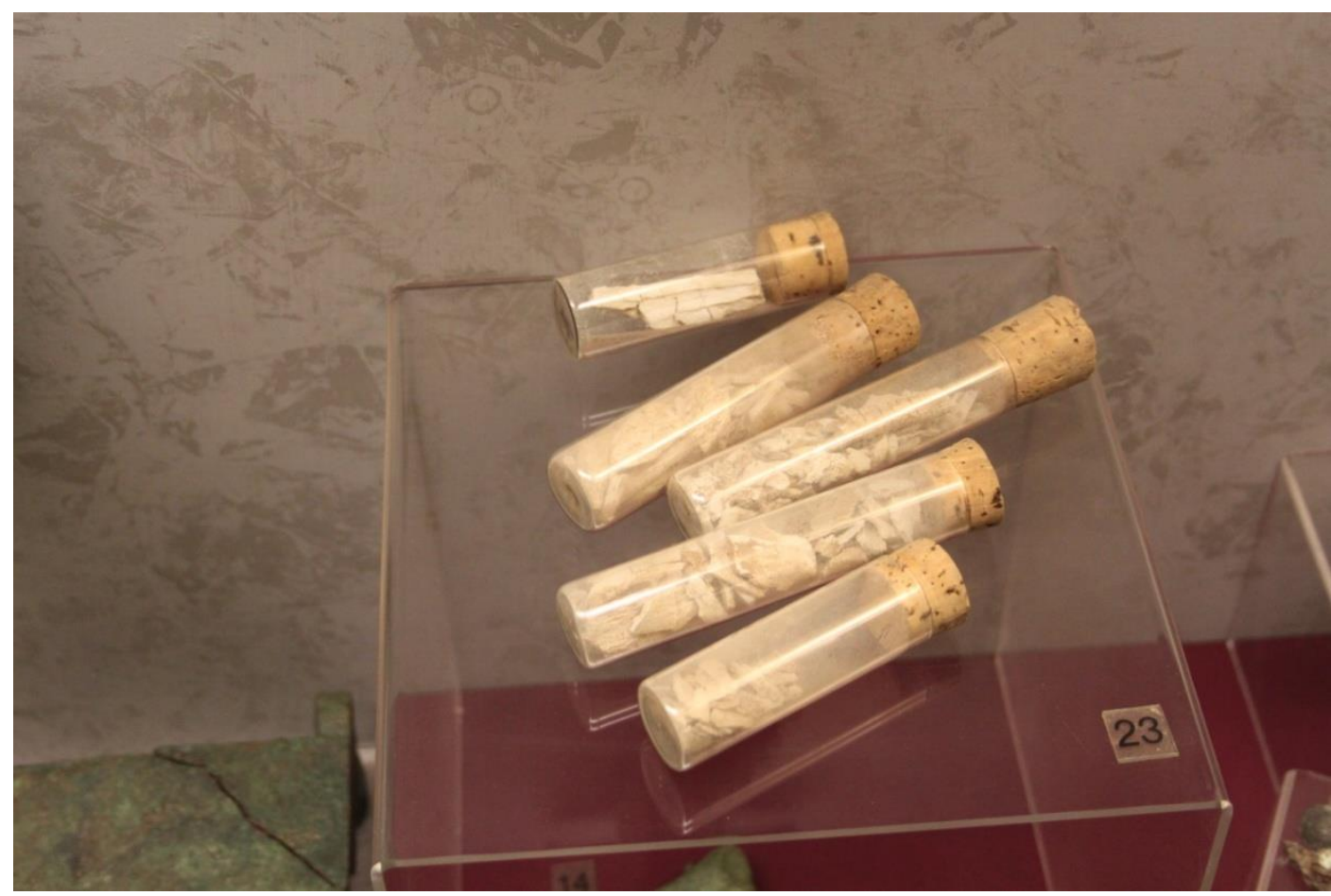

Fig. 14.6 Cremated human bone in test-tubes as retrieved from the Lexden Tumulus, CM (Photograph by Howard Williams 2012)

Despite CM inhabiting a pre-existing space, many of the same impressions are left to that afforded by HO. At both sites we have encountered a wide range of intelligent but straightforward display strategies for cremation in the human past, juxtaposed within the same museum. As with $\mathrm{HO}$, cremation processes are overlooked although the variability in cremation practices within and between time periods is exhibited but poorly explained and conflated within conventional cultural epochs. At both, there is no attention to cremation as a ritual technology but variability is made clear, implicit in the juxtaposition of many different types of cremation grave. A palpable difference from $\mathrm{HO}$ is the number of artefacts and assemblages from cremated graves displayed without the cremains.

Furthermore, the number of hidden and semi-concealed displays of burned human remains is more apparent, perhaps reflecting a lack of consideration for cremated human remains in contrast to the artefacts found in cremation graves. Also, at CM, the presentation of artefacts and ashes is restrained within the conventional display case and does not appear (as at $\mathrm{HO}$ ) beneath floors. 
A further striking difference from the Danish heritage site is how rarely the public are shown archaeological plans and photographs. While, the engagement with cremation is more conventional, and seldom lets the visitor into an understanding of the archaeological contexts from whence they were derived, CM reveals that complex and varied displays of cremation in the human past are integral, not only to bespoke single-phase displays at heritage sites, but to town and city museums with long histories of collecting and displaying mortuary remains.

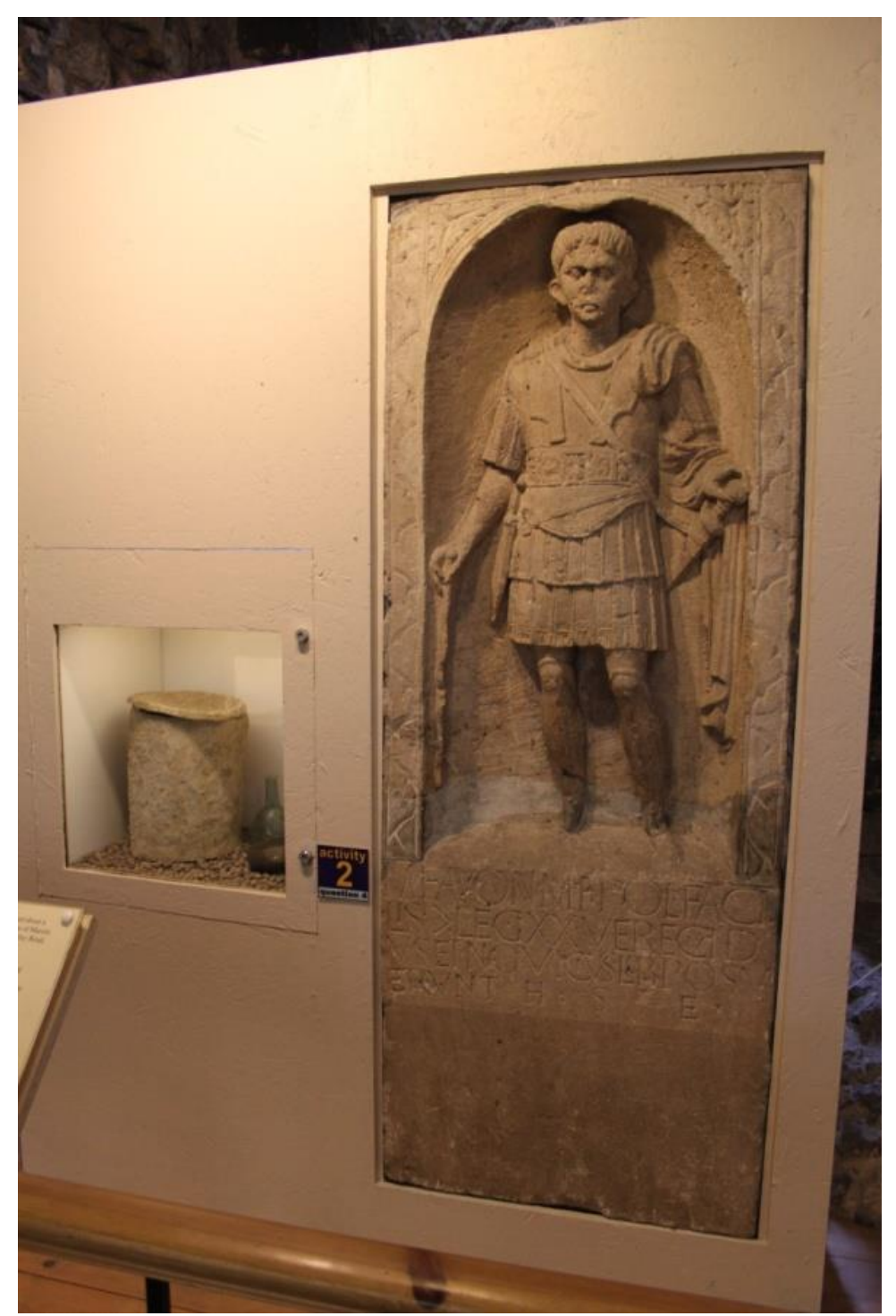

Fig. 14.7 The striking juxtaposition of the cinerary urn and tombstone of centurion Marcus Favonius Facilis $(\mathrm{CM})$, a rare instance where it is possible to view above- and below-ground mortuary components relating to the funeral of the same individual in a British museum (Photograph by Howard Williams, 2012) 


\section{MUSEUM SØNDERJYLLAND-A COUNTY MUSEUM}

The Museum of Southern Jutland (Museum Sønderjylland, hereafter MS) has its own archaeological museum and department-Arkælogi Haderslev_ situated in the town of Haderslev, Denmark (Table 14.4). The museum was established in 1887 and the building dates from 1977. In the grounds there is Denmark's oldest open-air museum, while inside the building are a range of archaeological displays narrating the region's prehistory and early history through a traditional archaeological narrative. The display was observed during a visit in September 2010 while I was attending the Internationales Sachsensymposion, hosted by the museum. Despite its regional coverage, the area for display is broadly comparable, perhaps slightly smaller space than $\mathrm{HO}$ and CM.3

There are numerous indirect traces of the ancient dead on display, as for example, the many weapons and other military artefacts associated with Roman Iron Age booty sacrifices from Ejsbøl; the bodies of defeated warriors are absent but implied through the treatment of the artefacts (Nørgård Jørgensen 2011). Likewise, among the artefacts and materials used to illustrate life in the region's past, many derive from mortuary contexts, including reconstructions of male and female Iron Age costume based upon gravefinds. There is even a diorama of the entrance of a Neolithic passage grave; human remains are absent, but the pottery and food arranged around the entrance speak of dialogues between the living and the dead among these early farming communities.

The ancient dead take many further forms and human remains are prominent at the museum despite the absence of an iconic bog body as found elsewhere in Denmark at, for example, the Moesgård Museum, Aarhus. At MS, the visitor encounters Bronze Age logcoffins containing well-preserved skeletons and their equally well-preserved clothing and artefacts. There are mock-ups of Iron Age inhumation graves achieved through depictions of clothed bodies (two-dimensional figures, not mannequins) accompanied by material culture. There are innumerable representations of site-based photographs, archaeological site-plans and grave-plans, and schematic cut-away representations of Bronze Age burial mounds, so that the material qualities and dimensions of sources of the evidence are readily accessible to the visitor. There is even an artist's impression of the actions required in the construction of a Bronze Age burial mound comprised of nine sequential frames of activities. There are five principal displays of past cremation that I wish to discuss in chronological order (Table 14.4). The first-MS1-is modest in appearance but significant in national terms as it claims to be Denmark's oldest grave. The 'Hammelev-gravenDanmarks ældste gravefund' display comprises multiple text panels supported by photographs with information about the ochre, flint artefacts, animal and human remains recovered, and the find's significance (Fig. 14.8). These surround a reconstruction of the grave itself, portrayed as revealed upon discovery and displayed beneath an irregular hexagonal display cabinet accessible from all sides. No attempt to reconstruct the deceased's identity is attempted; the find is portrayed for what it is: a modest, isolated discovery that is important for its early date: a narrative of obscure post-glacial origins. 
Table 14.4 Key displays of cremation at MS

\begin{tabular}{|c|c|c|}
\hline Cabinet & Type & Description \\
\hline \multirow[t]{4}{*}{$\begin{array}{l}\text { MS1, Grave from } \\
\text { Hammelev- Denmark's } \\
\text { Oldest Grave. }\end{array}$} & 1 & $\begin{array}{l}\text { Denmark's oldest grave dated to c. } 8,250 \mathrm{BC} \text { was first cremated. The cremains of an } \\
\text { adult together with a wildcat and tools were placed on an animal skin and sprinkled } \\
\text { with red ochre before being wrapped and placed in a hole } 70 \mathrm{~cm} \text { deep. }\end{array}$ \\
\hline & 6,8 & $\begin{array}{l}\text { Annotated photograph of the mock-grave accompanies the text panels. Other } \\
\text { photographs include photographs of the artefacts, human mandible and the } \\
\text { assemblage upon discovery. }\end{array}$ \\
\hline & 6 & Reconstruction of Denmark's oldest grave upon hexagonal plinth. \\
\hline & 8 & Photograph of the excavated assemblage on text-panel. \\
\hline \multirow[t]{2}{*}{$\begin{array}{l}\text { MS2a, A Grave from } \\
\text { Tappendalhøjen. }\end{array}$} & 1 & $\begin{array}{l}\text { The text describes a how the cremains of a } 30-50 \text { year old person with a razor and } \\
\text { awl were found amidst stones that may have supported a plank coffin. }\end{array}$ \\
\hline & 5 & $\begin{array}{l}\text { Un-urned cremains from Tappendalh } \varnothing \text { jen one a glass display shelf, together with } \\
\text { two bronze artefacts; a razor and sickle. }\end{array}$ \\
\hline \multirow[t]{3}{*}{ MS2b, A Family Tragedy? } & 1 & $\begin{array}{l}\text { The text describes the discovery of a double-grave of two individuals, an adult of } \\
30-50 \text { years and a child of } 2 \text { years and a } 20-35 \text { possible male. }\end{array}$ \\
\hline & 5 & $\begin{array}{l}\text { Un-urned cremains from the same site, possibly a family grave of two persons and a } \\
\text { child of } 2 \text { years, together with a range of bronze artefacts. }\end{array}$ \\
\hline & 8 & Excavation photograph of the cremation graves. \\
\hline \multirow[t]{2}{*}{$\begin{array}{l}\text { MS3, Urns from the older } \\
\text { barrow. }\end{array}$} & 1 & $\begin{array}{l}\text { Text panel explains that cremation replaced inhumation in the later Bronze Age } \\
\text { during the period } 1000-500 \mathrm{BC} \text { and the range of artefacts that can be found with } \\
\text { cremation graves dug into the edges of older mounds. }\end{array}$ \\
\hline & 2 & $\begin{array}{l}\text { Two shelves displaying eight cinerary urns of the Late Bronze Age. No cremains } \\
\text { included. }\end{array}$ \\
\hline \multirow[t]{3}{*}{$\begin{array}{l}\text { MS4a, Pre-Roman Iron Age } \\
\text { cremation cemetery, } \\
\text { Årupgård, 500-150 BC. }\end{array}$} & 1 & $\begin{array}{l}\text { Text panel introduces Arupgård as relecting the beginning of the Iron Age with } \\
\text { continuity from the preceding burial rites of the Late Bronze Age, with graves } \\
\text { increasingly placed under their own little mounds. }\end{array}$ \\
\hline & 5 & $\begin{array}{l}\text { Window in the text panel allows view back into the display of Late Bronze Age urns } \\
\text { - MS3 }\end{array}$ \\
\hline & 9 & $\begin{array}{l}\text { Text panel and window allowing a view of the Late Bronze Age urns is surrounded } \\
\text { by a colour artist's reconstruction of how the cemetery appeared, with small mounds } \\
\text { surrounding an older Bronze Age mound. Two figures walk away from the viewer } \\
\text { for scale. }\end{array}$ \\
\hline \multirow[t]{3}{*}{$\begin{array}{l}\text { MS4b, Pre-Roman Iron Age } \\
\text { cremation cemetery, } \\
\text { Årupgård, 500-150 BC. }\end{array}$} & 1 & $\begin{array}{l}\text { Text explaining the spatial organization of the cemetery including its division by } \\
\text { social group and wealth. Seven chronological divisions were identified based on the } \\
\text { brooches. A clear distinction in artefacts and urn-size between adults and children } \\
\text { and changes in the organization of ring-ditches are described. Miniature pots found } \\
\text { as grave goods across the cemetery. }\end{array}$ \\
\hline & 2 & $\begin{array}{l}\text { Four shelves stacked with cinerary urns from the same cemetery, a phenomenal } \\
\text { display of a wide range of vessels. The shelves are divided into seven vertical strips } \\
\text { according to colour, that mark the chronological development of the cemetery from } \\
\text { left to right. }\end{array}$ \\
\hline & $8 / 9$ & $\begin{array}{l}\text { Adjacent to the shelves of cinerary urns and on the wall to their left, an isometric } \\
\text { excavation plan of the barrow cemetery from whence the urns came, showing the }\end{array}$ \\
\hline
\end{tabular}




\begin{tabular}{|c|c|c|}
\hline & & $\begin{array}{l}\text { development focusing on Bronze Age barrows and depicting the nature of the } \\
\text { archaeological features uncovered. }\end{array}$ \\
\hline & 5 & $\begin{array}{l}\text { The front row of seven urns are associated with artefacts in front of them. Cremains } \\
\text { can be viewed within the urns without lids. Like the urns behind them, these vessels } \\
\text { are placed in chronological order, placed on a differently coloured surface that } \\
\text { corresponds with the colour-coded grave-plan. Each of the seven urns represents a } \\
\text { phase in the cemetery's evolution. }\end{array}$ \\
\hline & 9 & $\begin{array}{l}\text { A colour-coded cemetery plan, indicating the development of the cemetery over } \\
\text { time. }\end{array}$ \\
\hline \multirow[t]{5}{*}{$\begin{array}{l}\text { MS5, Early Roman Iron } \\
\text { Age Burial Customs }\end{array}$} & 1 & $\begin{array}{l}\text { The diversity of mortuary practice is explained, although the predominance of } \\
\text { cremation is stated, either in urns or in a pit without an urn. Inhumation is a new } \\
\text { burial rite. Details of the burial rituals are described, including evidence for paving } \\
\text { within cemeteries and pot-sherds scattered in graves, the process of cremation } \\
\text { including the care taken to retrieve ashes and wrap them in cloth, and the artefacts } \\
\text { placed in cinerary urns. }\end{array}$ \\
\hline & 6 & $\begin{array}{l}\text { Schematic representations of two inhumation graves and three cremation graves } \\
\text { reconstructed elsewhere in the same display }\end{array}$ \\
\hline & 6 & $\begin{array}{l}\text { Adjacent to mock-ups of an adult female inhumation grave containing grave-goods } \\
\text { and an outline of a costumed figure rather than a skeleton, there are three different } \\
\text { mock-ups of cremation graves of early Iron Age date, one un-urned and two urned } \\
\text { (one open, one with a lid in place). All these are into a brown display case to imply } \\
\text { the earth. All three can be viewed through glass from above, while the two cinerary } \\
\text { urns can also be viewed from the side. The un-urned cremation is accompanied with } \\
\text { weaponry, the urned cremains are placed with artefacts.Behind is an artist's } \\
\text { impression of a cremation ceremony. }\end{array}$ \\
\hline & 9 & $\begin{array}{l}\text { A panorama of an Early Roman Iron Age landscape with a funeral in progress, and } \\
\text { burial mounds of different sizes, presumably implying those covering both } \\
\text { inhumation and cremation graves, with a settlement in the distance. }\end{array}$ \\
\hline & 9 & Artist's impression of an Early Roman Iron Age open-air cremation. \\
\hline
\end{tabular}

In contrast to this attempt to portray the archaeological context of a primordial individual, a display case of Bronze Age finds (MS2) portrays cremains as a context-free pile of material, where artefacts found associated with them are placed separately with an accompanying text panel postulating whether the burial of a child and two adults reflects 'a family tragedy'. MS3 is also a conventional display of Late Bronze Age cinerary urns and artefacts, with no cremains displayed. Moving into the Pre-Roman Iron Age, $\mathrm{MS}_{4}$ is an intelligent and powerful display on a number of levels, using the vast quantity of urns and grave-goods from a single barrow-cemetery to superb effect, together with artist's reconstructions and colour-coded cemetery plan, to communicate aspects of both the continuity and variability of mortuary practice during the second half of the first millennium BC. The use of multimedia supporting the careful arrangement of cremains and artefacts, and the inclusion of a large number of items, are all commended in affording a sense of mortuary practice and variability (Fig. 14.9). Finally, we come to the use of inhumation and cremation during the Roman Iron Age (MS 5 ) where the considered use of multiple media includes mock-ups of inhumation juxtaposed with three very different cremation graves. The combination with two artists' impressions-one of an Iron Age landscape and one of a cremation pyre alight-provide spatial context to the mock-graves (Fig. 14.10). 
While offering a different permutation of display methods, MS is similar to $\mathrm{HO}$ and CM in its diversity of techniques and the mix of single graves serving to illustrate a time period and multiple graves to illustrate the variability in cremation practice within and between epochs. Where MS differs is in attempting to portray the cremation process through artist's reconstructions: a major omission in the other museums.

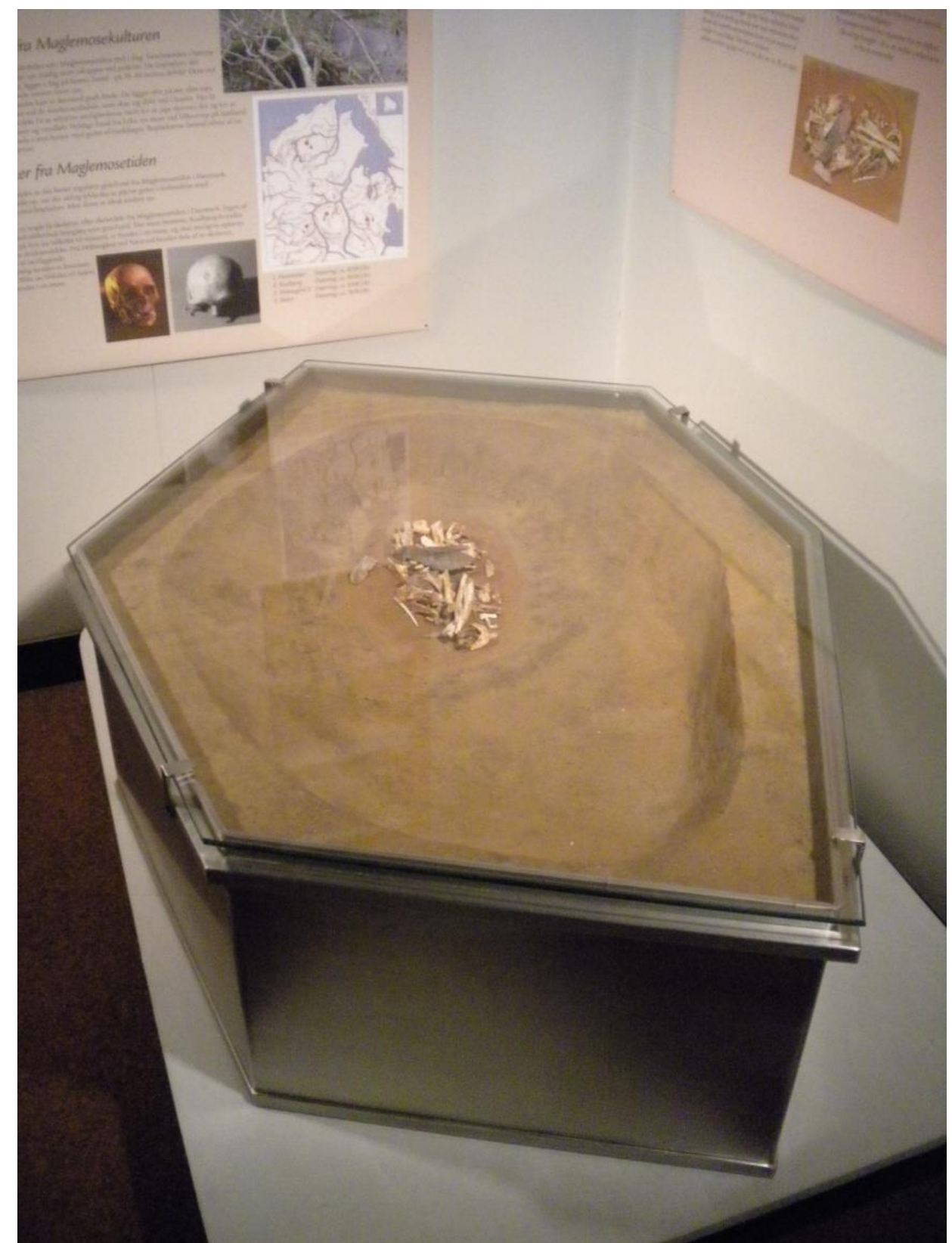

Fig. 14.8 Denmark's oldest grave, MS (Photograph by Howard Williams, 2010) 


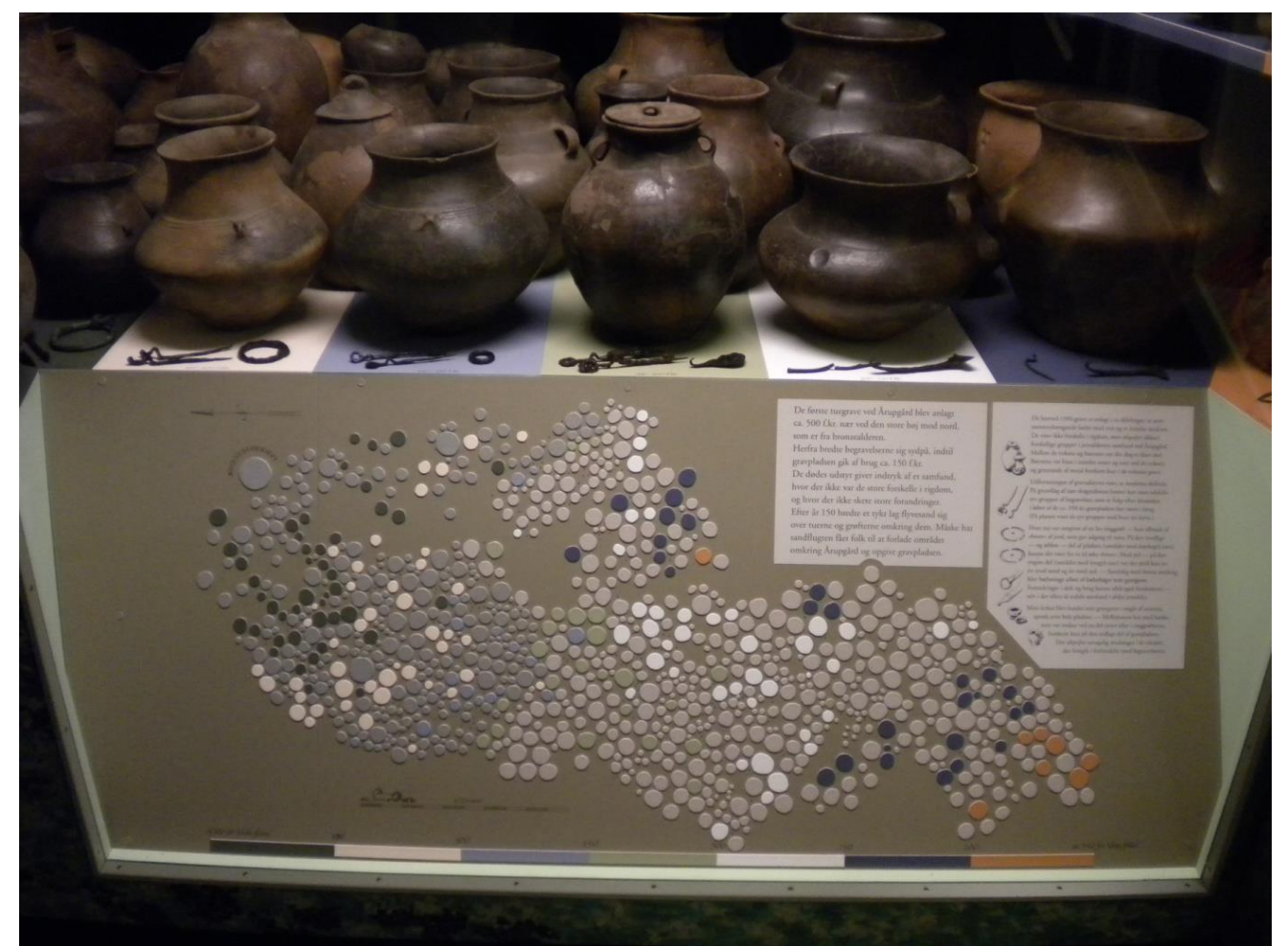

Fig. 14.9 A plan of an Iron Age urnfield with pots representing each chronological phase, MS (Photograph by Howard Williams, 2010)

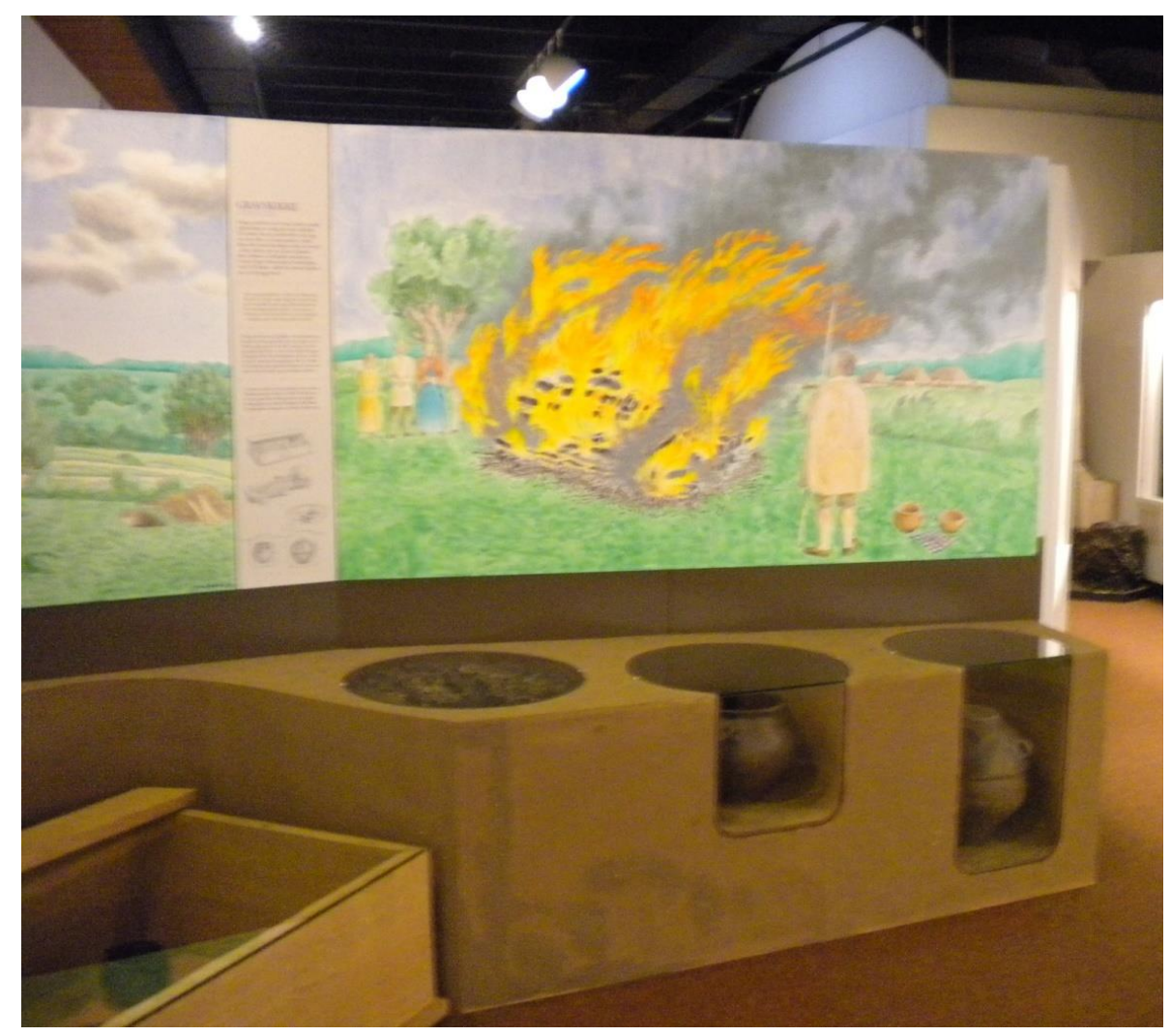

Fig. 14.10 Mock-graves and illustration of an Iron Age cremation, MS (Photograph by Howard Williams, 2010) 
Table 14.5 Key displays of cremation at HM

\begin{tabular}{|c|c|c|}
\hline Cabinet & Type & Description \\
\hline \multirow[t]{2}{*}{$\begin{array}{l}\text { HM1 - Hasslöv Late } \\
\text { Bronze Age } \\
\text { Cremations }\end{array}$} & 1 & $\begin{array}{l}\text { Text panel explains the cremation context and likely family affiliation } \\
\text { of the occupants of the graves and asks whether the items were } \\
\text { personal possessions. }\end{array}$ \\
\hline & 5 & $\begin{array}{l}\text { Nine cinerary urns, artefacts, and silhouettes to denote the age and } \\
\text { gender of the deceased individuals found with three each. }\end{array}$ \\
\hline \multirow{3}{*}{$\begin{array}{l}\text { HM2 - Children from } \\
\text { Bankälla }\end{array}$} & 1 & Text panel and audio (in Swedish) \\
\hline & 5 & $\begin{array}{l}\text { Six burial assemblages on small separate shelves upon a vertical } \\
\text { surface, comprising the cremains of a neonates, infants and a young } \\
\text { child with their ceramic urns (for five assemblages) and artefacts (for } \\
\text { one assemblage). }\end{array}$ \\
\hline & 9 & $\begin{array}{l}\text { Translucent fabric hanging with photographs of two children in Iron } \\
\text { Age clothing, the older behind and with arms around the younger } \\
\text { child's neck implying familial affection. }\end{array}$ \\
\hline \multirow[t]{5}{*}{$\begin{array}{l}\text { HM3 - The man from } \\
\text { Krankmartenhögen, } \\
\text { Norrland }\end{array}$} & 1 & $\begin{array}{l}\text { A text panel explains the burial of a man dated to the early first } \\
\text { millennium AD from northern Sweden, asking the question, 'can we } \\
\text { really say these were Saami'? }\end{array}$ \\
\hline & 6 and 7 & $\begin{array}{l}\text { A modest collection of cremains is placed at the front of a corner- } \\
\text { display without the bark container in which it was found. }\end{array}$ \\
\hline & & A stone cairn is implied by a display of boulders beneath the antlers. \\
\hline & & $\begin{array}{l}\text { Reindeer and elk antlers provide a sense of the, reflecting the material } \\
\text { found in }\end{array}$ \\
\hline & 9 & $\begin{array}{l}\text { A panoramic artist's impression of how the cemetery may have } \\
\text { appeared overlooking the lake, each cairn covered with reindeer and } \\
\text { elk antlers. }\end{array}$ \\
\hline \multirow[t]{3}{*}{$\begin{array}{l}\text { HM4 - the man from } \\
\text { Kisselby, Norrland }\end{array}$} & 1 & $\begin{array}{l}\text { Text panel gives basic information about the status and likely external } \\
\text { contacts of the occupant of the grave from Norrland. }\end{array}$ \\
\hline & 2 & $\begin{array}{l}\text { Around the central display are discrete clusters of artefacts from within } \\
\text { the cremation burial - glass, ceramics, arrowheads and bear claws. }\end{array}$ \\
\hline & 5 & $\begin{array}{l}\text { Cremains of humans and animals are contained within a bronze } \\
\text { cauldron and topped by bear bones. }\end{array}$ \\
\hline \multirow[t]{2}{*}{$\begin{array}{l}\text { HM5 - Köpingsvik, } \\
\text { Öland. }\end{array}$} & 1 & $\begin{array}{l}\text { Text panel explaining the wealthy artefacts from this Vendel Period } \\
\text { cremation grave. }\end{array}$ \\
\hline & 2 & $\begin{array}{l}\text { Open casket implying a jewellery box within which are } 25 \\
\text { compartments of equal size from a rich eighth-century female } \\
\text { cremation. } 9 \text { contain cremated artefacts, arranged by artefact-type. }\end{array}$ \\
\hline
\end{tabular}




\begin{tabular}{|c|c|c|}
\hline & 4 & $\begin{array}{l}\text { The remaining } 16 \text { compartments contain cremated human and animal } \\
\text { bone. }\end{array}$ \\
\hline \multirow[t]{2}{*}{$\begin{array}{l}\text { HM6 - Heathen } \\
\text { Woman of Power, } \\
\text { Köpingsvik, Öland. }\end{array}$} & 1 & $\begin{array}{l}\text { Text panel explains that the artefacts of 'majestic splendour' included } \\
\text { powerful symbols of heathen magic and worship, suggesting a leading } \\
\text { religious role and symbol of aristocracy. }\end{array}$ \\
\hline & 2 & Individual artefacts arranged in display case. \\
\hline \multirow[t]{3}{*}{$\begin{array}{l}\text { HM7 - Who owned the } \\
\text { brown hair? Adelsö, } \\
\text { Lake Mälaren }\end{array}$} & 1 & $\begin{array}{l}\text { Description of a cremation under a large mound producing evidence } \\
\text { for a plait of brown hair. The text speculates that she may have been a } \\
\text { human sacrifice at a male funeral. The sacrifice of horses and dogs, as } \\
\text { well as cat, sheep, swine, pike and various birds are mentioned. }\end{array}$ \\
\hline & 2 & $\begin{array}{l}\text { An assemblage of artefacts from a rich cremation burial including } \\
\text { glass gaming pieces and horse bridle situated around the vessel } \\
\text { containing cremains. The human hair is prominently displayed. }\end{array}$ \\
\hline & 5 & Cremains within large bronze bucket \\
\hline $\begin{array}{l}\text { HM8 - Video of Re- } \\
\text { enacted Boat- } \\
\text { Cremation inspired by } \\
\text { the account of Ibn } \\
\text { Fadlan. }\end{array}$ & 9 and 10 & $\begin{array}{l}\text { Short looped video of scenes from the preparation and cremation of a } \\
\text { deceased Viking leader within a boat. }\end{array}$ \\
\hline
\end{tabular}

\section{HISTORISKA MUSEET-A NATIONAL MUSEUM}

My final example is a national museum, the Historiska Museet (HM),Stockholm, Sweden (Table 14.5).4 Almost every period of Sweden's past is represented by the range of human remains within HM's galleries. Human remains saturate the chronologically arranged Prehistories 1 gallery (see Bünz 2012) as well as the thematic Prehistories 2 gallery and the Viking gallery. The new History of Sweden gallery charts the nation's development from the eleventh century to the present day and human remains are integral to the narrative. Human remains are unsurprisingly absent from the Gothic Hall (Medieval Ecclesiastical Art), Textile Chamber, and Gold Room, but these spaces too contain many material cultures and monuments associated with the commemoration of the dead and/or found in graves. The most recent human remains on display include a syphilitic skull that provides a grisly memento mori and counterpoint placed on a mirror-backed dressing table display about eighteenth-century, 'culture: fashion, beauty, vanity'. Close by, a skull bearing distinctive tooth-wear illustrating the habit of smoking clay pipes is part of a display on the 'products of slavery'.

The relatively new Prehistories gallery (opened in two stages between 2005 and 2008) is replete with human remains, with an overarching emphasis upon narrating what can be told about the lives and cultures of individuals. It is through such 'immortals', such as the Bäckaskog Woman, portrayed as a powerful huntress (see Bünz 2012; Nordström 2007, this volume), the Mesolithic Skateholm double grave of an elderly man and child, and the Roman Iron Age 'woman from Gårdlösa', that the visitor walks through Swedish prehistory from the last Ice Age to the Vendel Period. In the absence of human remains, martial and feasting assemblages from the Vendel boat-graves create a world of the living, rather than 
that of the dead, an idealized vision of lordly life focusing on the hall's high-seat and hearth. In the Viking gallery, identities for the dead are displayed without human remains including the display of rune-stones and Gotlandic picture-stones and an artist's reconstruction of a Viking adult female's inhumation grave illustrating the passage from 'Heathen to Christian' at the Valsta, Uppland cemetery.

Among this range of human and mortuary remains, $\mathrm{HM}$ has constructed many different stories and identities for the cremated dead, revealing both innovative display strategies and profound tensions and confusions over how to deal with the cremated dead in the modern museum context. At one level, cremation is of limited use in charting the appearances and identities of individuals, but affords possibilities for the creation of other kinds of narratives. In this regard, the HM is perhaps more polarized in its treatment of cremation than the other museums considered so far, possibly reflecting different curators' ideas and the diversity of challenges inherent within the wide range of material on display in a national museum.

Artefacts are displayed that are inadequately connected to their cremation contexts, such as the three Thor hammer-rings on display in the Viking gallery (see Andersson 2005). In contrast with the other museums discussed, the HM galleries fail to tackle prehistoric mortuary variability, but in common with the others they afford limited attention to why some past cultures cremate or use other disposal strategies; burned and unburned human remains are simply juxtaposed without explanation.

In the second half of the Prehistories gallery, ironically one of the most recent, cremation is more often neglected; the texts describe 'human bones' and 'bones' without reference to cremation, and there is no commentary in the context, significance, and variability of the mortuary practices from which the bones derive. Even when a burial assemblage (category 5 ) is partially reconstructed, the text panel does not mention the association with cremation ritual, and instead states boldly: 'Wooden trough with bones of human, cow, swine and sheep or goat/ Skåne, Simris, Viarp/ 1100-50o f $\operatorname{Kr}(B C)^{\prime}$. Elsewhere, houseshaped urns (category 2) from Skåne, Småland, and Gotland are dislocated from cremation; nothing is said about their use as cinerary urns or associated with cremation practices. Likewise, in the first half of the Prehistories gallery, heavily fragmented burned bones from the site of Lunda, Södermanland, are displayed in a cabinet under the title 'gods and sacrifices' without entertaining an association with cremation or other fire rituals (Andersson 2006: 196). In the Viking gallery, there is a pair of reconstructions of the Valsta cemetery by the same artist supported by a bilingual text panel entitled 'Heathen to Christian in Valsta', yet the presence of both cremation and inhumation graves at the cemetery is overlooked in the narrative presented (Andersson 1997).

Some display strategies found elsewhere are not apparent: there are no reconstructed contexts for cremation graves and no unambiguous displays of monuments relating to cremation practice (category 3). Notably, excavation plans and photographs of cremation graves only appear in a part of the exhibit about the history of archaeology, with a photograph of a cut-through section model of the largest mounds at Gamla Uppsala, a photograph of the mounds under excavation, and a display copy of the excavation report (category 8). 
Between these extremes, cremated human remains challenge attempts to reconstruct the individual and their life ways, but do provide opportunities to construct alternative narratives about past societies and their mortuary practices. However, because of the obsession with the individual, these attempts are only partially effective. I here focus upon eight displays at $\mathrm{HM}$ that illustrate the variability. Five $\left(\mathrm{HM}_{1}-5\right)$ are from the Prehistories gallery, and three (HM6-8) from the Viking gallery (Table 14.5).

The first of our eight is perhaps the most effective and notably does not contain any cremated human remains; this is a display of artefacts from nine late Bronze Age cinerary urns from the cemetery of Hasslöv, Halland: HM1: Fig. 14.11). These are presented upon angled niches on two levels, four on the upper, five on the lower. Each urn is different in form, invoking a sense of the individuality of those within. This is drawn out by the decision to place the artefacts found within the urn on horizontal space below their pedestals, and in between each urn and grave-goods, a silhouetted profile of a head is added, alluding to the age and gender of the individuals reflected in the artefacts found (and possibly the bones, but this is not made clear). Intriguingly, this very effective display strategy works without cremated human remains, showing how the absence of cremains need not restrain the use of material culture to articulate the cremated dead, past identities, and socialities. Unfortunately, the evidence behind the presentation of age and gender is not made clear. All that is said about the osteological evidence behind the identification of each silhouette is a general statement articulating their youth. What this display strategy does possess is an emphasis upon the mortuary context of a cemetery comprised of burial mounds in which individuals of varying social identities were interred in varied kinds of cinerary urn. However, the attempt to impose both an individual, and a kinship identity, upon the remains by framing the display as 'The chief and his relatives' does not fully marry up with the impression the display presents to the visitor of greater communality. This is because, while the 'chief ' is given double the space-one for his urn, one for the bronze dagger and sheath found with him-beyond that, his modest urn and lack of other evidence of high status means that a relative equality in death is projected. By drawing on a range of graves from the same cemetery, the display affords a sense of both the individuals behind the graves, and a sense of a community in death. In both these regards, this is a strikingly rare and important display, since this is hardly ever attempted for the cremated dead even when their remains are found in cemeteries of tens or even hundreds of discrete burial deposits. Disappointingly, little is said about the cremation ceremonies of the time and their variability between funerals and over space and time. Also, the significance of the urn remains unstated - nothing is said of the choice and character of the funerary vessels-let alone the artefacts found therein. 


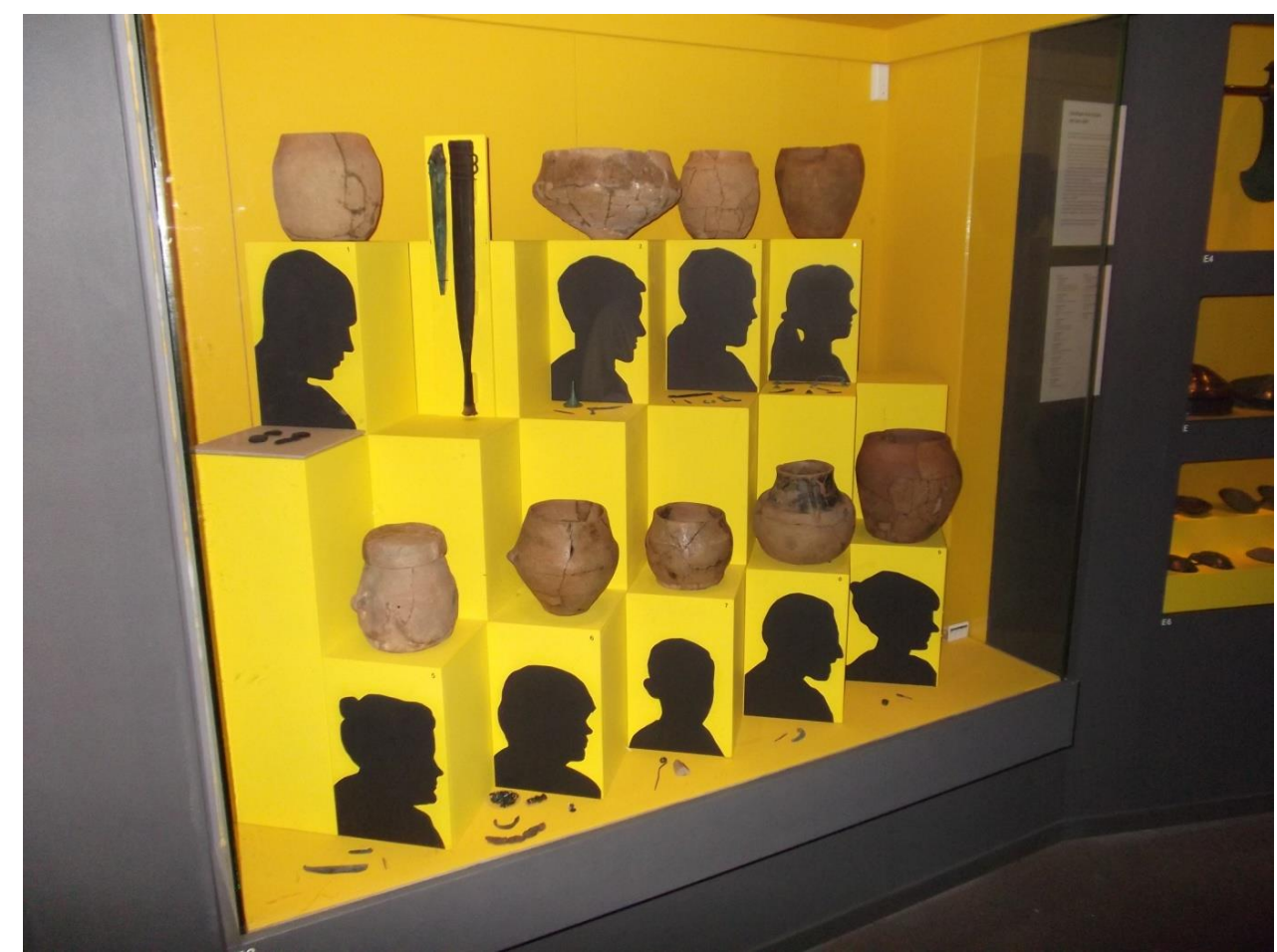

Fig. 14.11 Bronze Age cremations with silhouettes of their occupants, HM (Photograph by Howard Williams, 2012)

Moving into the Pre-Roman Iron Age, we find a different display of cremated remains entitled 'Barnen från Bankälla' (children from Bankälla: HM2). Again an impression of context is afforded by using child-graves from the same cemetery. Five cremation urns and one cremation deposit constitute the display, containing the remains of newborn and young infants, and in one case, a child of 6-7 years at the time of death. There are practical problems with this display: the numbers on the text panel are not replicated in the display, leaving some ambiguity as to which is which. But here we find the diminutive nature of these dead individuals, exacerbated by the stark yellow vertical wall upon which they are widely spaced, and hence implying something of the reality of infant mortality in the past and the emotive nature of this loss. This is brought powerfully home through a photograph printed on a semi-transparent textile-hanging: with a backdrop of farmland there are two children in prehistoric dress, the elder one smiling and embracing the younger. Again, here is an attempt to connect to individuals through the display of human remains. However, once more, nothing is said regarding the cremation process or archaeological interpretations of these, or how these graves compare to those of older juveniles, subadults, and adults from the same era. Equally there is only a limited sense of cemetery, monument, or landscape context.

Moving to the late Iron Age, we encounter an opposition of two cremation displays ( $\mathrm{HM}_{3}$ and $\mathrm{HM}_{4}$ ). First, cremated human remains are encircled by traces of the resin used to seal its original organic container. Above these, a sense of the stone cairn raised over the graves is provided by a single spread of boulders lain into the available space. These are covered by the skull-top and horns of elk and deer, reflecting the evidence that these had been placed on the monument ( $\mathrm{HM}_{3}$ : Fig. 14.12). Above and behind these again, there is an artistic reconstruction of how the cemetery may have appeared: a panoramic backdrop illustrating the linear arrangement of monuments along the prominent ridge and its wider landscape 
situation in relation to hills and lakes. This serves to simultaneously provide the sense of a burial community of repeated monumental graves which is sadly lacking in the text that focuses on the treatment of the single grave. There is clearly, once again, a tension between attempting to talk about individuals and the emphasis upon the communal cemetery context. A further aspect of identity is negotiated; the display asks: 'can we really say these were Sámi'? Nothing further is stated about the debates regarding this issue in Swedish archaeology. A further sense that this cemetery was situated in an inland landscape is a projection of a waterfall while on the floor, a 'river' trails across towards an opposing display of a 'man from the coast'.

The opposing display is from a grave at Kvissleby $\left(\mathrm{HM}_{4}\right)$. With a projection of a coastal landscape reached by the 'river' on the floor, this individual's display lacks any further landscape context beyond a statement that there were many burial mounds in the area. While the 'man from the inland' is one of a community of graves that are not talked about, the desire to discuss the individual male identity of the Kvissleby grave is in tension with the statement that the cremated human material contained within were from both a man and a woman. Still, the advantage of foregrounding the male identities present in both graves allows comparisons and contrasts to be considered between the inland and coastal regions and their different societies and burial traditions. The Kvissleby grave is a reconstruction of a burial context: the burned human remains are displayed in a large bronze vessel covered with birch bark and containing glass, ceramics, arrowheads, and bear claws displayed around them. Yet the identity of the female in this grave is omitted, revealing a clear masculine bias in the narrative constructed.

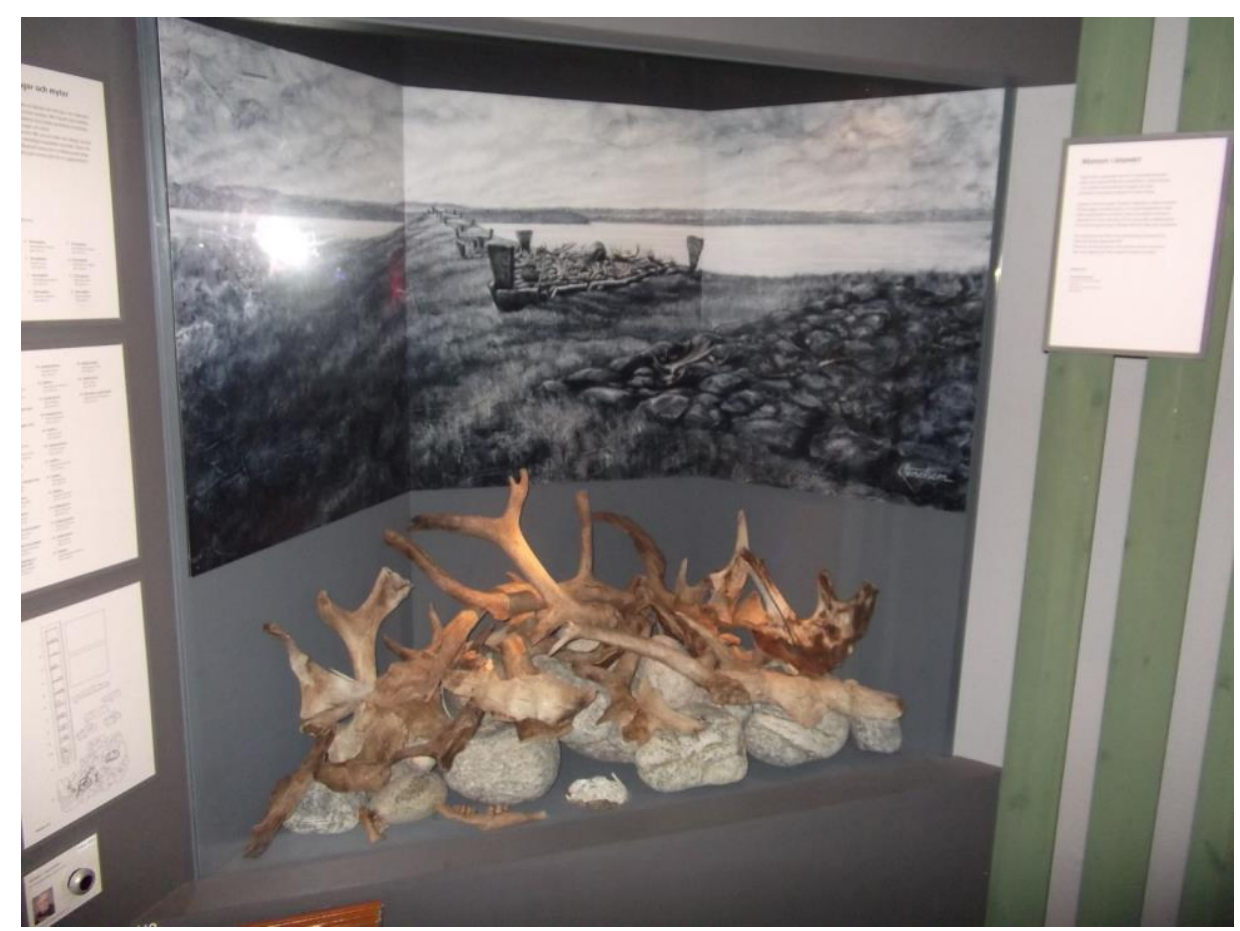

Fig. 14.12 Iron Age cremation from northern Sweden, HM, including artwork by Mats Vänehem (Photograph by Howard Williams, 2012)

A further kind of anonymity is found juxtaposed against the absence of human remains in the Vendel period boat-grave treasures $\left(\mathrm{HM}_{5}\right)$. In a single case, the vertical display, 
arranged to imply an opening casket, are a range of female-gendered artefacts, all from graves from the island of Gotland, apart from finger-rings from Södermanland. These inform, and give context to, the horizontal display at the bottom of the cabinet. The materials in the horizontal display within the same case are all from the same high-status female cremation grave from Öland and dated AD 700-800 (see Svanberg 2003: 132-3; Fig. 14.13). The fact that they come from a single context is not made clear to the viewer as there is no allusion to landscape or cemetery context, monument, grave-plan, or photos. The remains from this grave are arranged in square boxes, arranged in a grid of five by five, giving twenty-five spaces. Sixteen of these (all of the back row, partly overshadowed by the vertical display and difficult to see, and subsequent four, three, two, and two of each subsequent row) contain cremated human material. None is labelled and cremated material is not mentioned outside of the text panel. Here cremation is rendered present materially, and absent in terms of interpretation, gap-fillers to the nine boxes containing gold jewellery, necklaces, garnet jewellery, gold and glass, horse harness, casket fragments, a mirror, and a key. It is mentioned that the person was cremated in a boat or wagon, with a range of animals, but these are not explicitly displayed, although they may be mixed in with the cremated human material on show. The relationship with the surrounding treasures of the male boat-graves form Vendel remains implicit and one of simple juxtaposition, rather than explicit comparison and contrast. Relations between the male and female spheres is emphasized by the fact that the display is surmounted by a large photograph of an embracing couple from a Vendel-period gold-foil figurine, while the focus on female body is implied through close-up photos of a model combing her hair with the comb on display, wearing brooches, and two rings. Yet it might be argued that this focus on intimate female attire and body grooming contradicts the material evidence on display. Instead, the evidence reveals the importance of animal sacrifice and boats in the funerary process of cremation. 


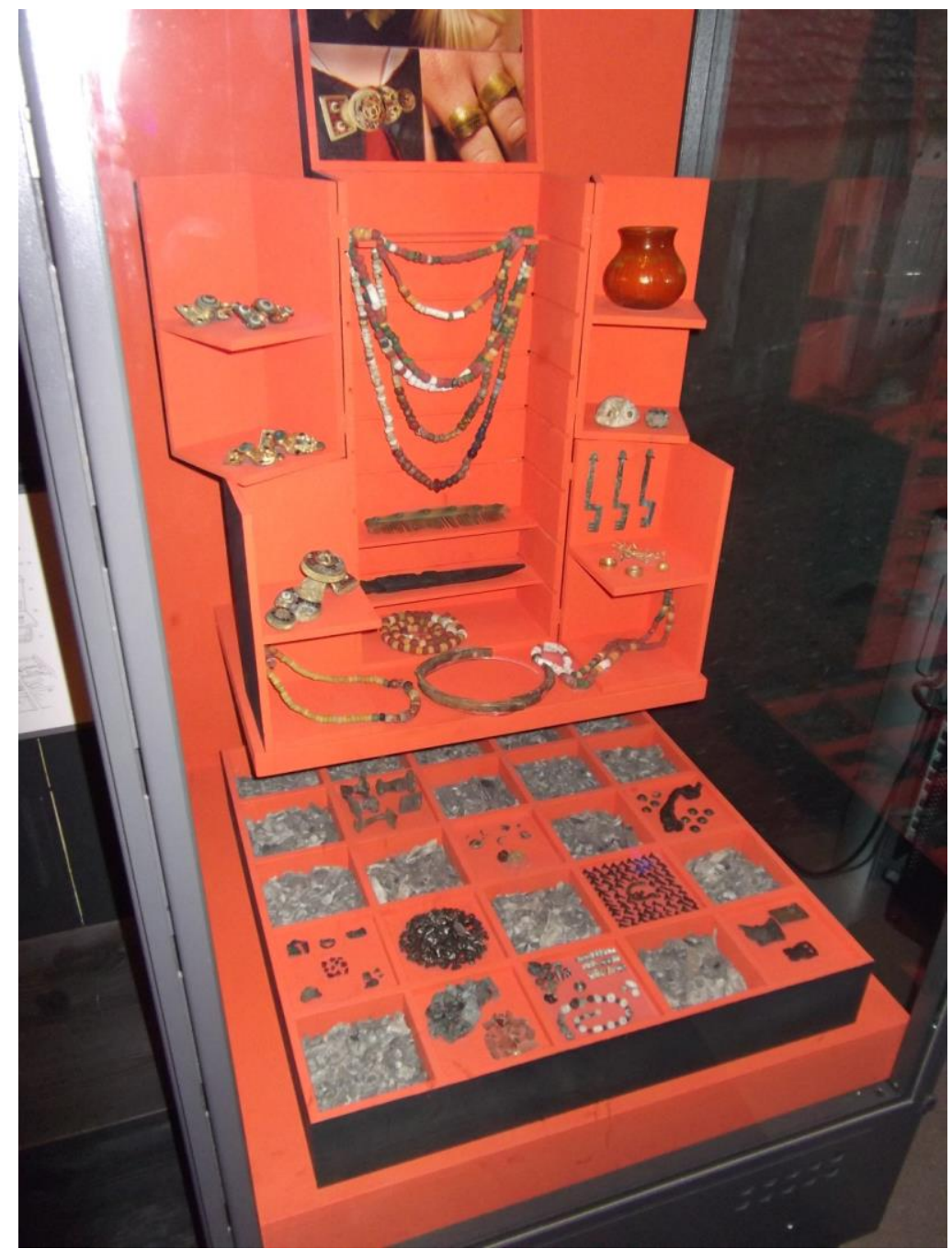

Fig. 14.13 Display of female jewellery from late Iron Age inhumation graves (vertical display) and twenty-five compartments containing the artefacts and cremains from a rich Vendel-period female cremation grave from Öland, HM (Photograph by Howard Williams, 2012)

Moving into the Viking gallery, the majority of the artefacts on display are from mortuary contexts, and some from cremation graves. For example, in a display of a rich cremation grave from Öland in the Viking gallery, the artefacts are presented but not the human remains (HM6). In a comparable display 'Who owned the brown hair?' a rich female cremation from Adelsö (HM7) comprises the reconstruction of the original context with bones in a bronze vessel and surrounded by the grave-goods found within. The final display worth noting in the Viking gallery is a looped video of an open-air cremation of a ship upon a pyre with actors shown bringing the corpse and laying it to rest in the boat and the placing of a dead dog with his body (HM8). Warriors clash their shields as the flames rise higher. This was a Russian-made film, apparently inspired by the account of Ibn Fadlan on the banks of the River Volga (Svanberg, pers. comm.). The scenes observed by Ibn Fadlan that involved the rape and violent slaying of a slave-girl are, unsurprisingly, omitted from this reconstruction, although something of the process of cremation is vividly invoked. What is apparent is that the Viking gallery tenaciously retains a pan-Nordic vision of Viking mortuary practice, with little of the local and regional variability explained in the disposal of 
the dead by cremation and inhumation explained. Cremation is portrayed as part of a normative Viking culture (cf. Svanberg 2003).

\section{CONCLUSIONS}

This chapter has identified a significant lacuna in our current research and debates over the display of the dead in museums and heritage contexts. To date, the widespread and varied displays of cremated bone in British and Scandinavian museums, and found widely throughout Continental Europe too, have been systematically overlooked in discussions of the display of human remains in museums. Instead debates have foregrounded articulated skeletons, bog bodies, and mummies. In order to investigate and redress this imbalance, I have focused on four case studies, and deliberately selecting those that I consider to have plentiful, varied, and carefully designed installations of cremated human material on display alongside unburned fragmentary and articulated skeletal remains. In doing so, the chapter has explored the variability in the display of the cremated dead and their distinctive and widespread presence as integral components of heritage sites as well as town, regional, and national museums.

The chapter has identified some critical concerns with how we display cremated human remains presently with clear ramifications for both future curatorial practice and broader debates regarding the roles of the archaeological dead in public archaeology and contemporary society. This is because, even in these modern, well-presented museum displays, cremation often remains poorly explained and inconsistently taken into consideration at present. Frequently, the cremated dead for any particular period or region are treated in normative terms that implicitly caricature the practices and communities they represent in relation to out-moded and misleading culturehistoric paradigms. Another problem with this approach is that it fails to explore the varied and complex uses of cremation in relation to other disposal strategies for the dead and their social, economic, and ideological contexts. Often the cremated dead are simply rendered mute, anonymous, and amorphous in the modern museum.

A particular issue regarding the display of cremation is that context is often downplayed and, in particular, past cremation ceremonies and mortuary environments are rarely visualized and explained. In many displays, cremated human material is treated akin to artefacts and afforded little or no interpretation as pertaining to past human lives and past mortuary practice. The cremated dead are even sometimes obscured from visitor experience with no explanation, as when ashes are half-hidden and sometimes fully concealed within vessels and containers, or else fully visible and yet without any caption explaining that they are even human remains and/or have been affected by fire. Thus, a key criticism of current museum displays is the lack of attention to the spectacle and tempo, multi-stage and sensory nature of cremation processes, and relationships with other contemporary disposal methods.

However, the situation is not that negative, and this study has attempted to foreground many positive aspects of the complexity and variability of cremation in the museum, both in terms of material presences and the narratives and identities displays convey. Each of the museums featured in this paper show fascinating and innovative attempts to display the cremated dead and cremation-related contexts and thus articulate dimensions of life 
and death in the human past. Within each of the case studies, the cremated dead are arranged and presented to perform many different narratives from those afforded to articulated skeletons and mock-ups of inhumation graves, thus the cremated dead in museums acquire varied and distinctive identities. Individuality is never completely lost with the cremated dead, and although they rarely take centre stage as discrete individual personalities for the modern visitor, this can occur, as with the Mesolithic cremation from the South Jutland Museum or the combination of urn and gravestone of the centurion Facilus at Colchester. The same can be said for the striking instance of the mock-up of the late Iron Age cremation grave from Welwyn Garden City on display in the British Museum: here a single wealthy grave with Mediterranean imports takes on a prominent position to narrate a key moment in British proto-history. An important point is that the scale and character of cremation allows for both individual and communal identities to be explored in museum contexts in fashions that assemblages and human remains associated with the, articulated and unburned dead cannot achieve. Frequently therefore, rather than the pervading sense of 'immortal ancestors' created through the display of individual single skeletons (see Nordström this volume), collections of displayed cremation burials and/or urns can characterize entire communities and their changing mortuary traditions over time, as with pre-Roman Iron Age urns at the Museum Sønderjylland (MS4). Elsewhere, cremations operate in supporting roles to articulated remains from inhumation graves, but even when artefacts are selected and cremated remains are obscured or absent, there is potential to communicate past death ways in intelligent and evocative fashions as illustrated by the Bronze Age burials displayed in the Historiska Museet, Stockholm (HM1).

Cremated human remains may be a challenge to communicate past individual lifeways to museum audiences, but this study shows how they do serve to convey alternative stories and identities about the human past. Cremated human material can be displayed to imply aspects of the archaeological contexts from whence they came and to create senses of past mortuary activity and the variegated social identities of those subjected to cremation. The cremated dead can be displayed in stark isolation but also as part of grave assemblages, and within mock-graves and memorials. Furthermore, the cremated dead can be absent, yet still vividly invoked through assemblages, vessels, artists' impressions, site photographs, and plans. The fragmented and portable, and hence versatile nature, of cremains facilitates their inclusion within display cases in association with material culture in fashions that unburned and articulated remains cannot, often allowing aspects of mortuary variability to be addressed by displaying many dozens of cremation assemblages in close association. Therefore, text, images, material culture, and architectural settings are combined with burned bones to make the cremated dead narrate vivid and lucid themes of life and death in the modern museum.

Inevitably this variation is in response to the contrasting biographies of each museum, the agency of successive museum curators, as well as the limitations on space and budgets affecting individual collections. While much remains unsatisfactory and ill-considered, I contend that the variation identified also reveals the challenges curators face and the innovative solutions some have already devised in dealing with the ubiquitous remains of the cremated dead. 
In the context of this book, these observations are crucial in identifying how the archaeological dead 'speak' to the living, not only by revealing aspects of past life and death ways, but also allowing historical reflection on the contemporary widespread use of cremation in contemporary society. By considering cremation, it is clear that the archaeological dead in European museums perform variegated narratives and identities about life and death in the human past and also inform how we deal with mortality in the present. Cremation is one of a series of ways that museums narrate mortality outwith the abject cadaver which is the concern of many chapters in this book. The cremated dead are frequently less human-like, more 'dead', and provide different, less emotionally jarring, and yet equally rich and varied stories to tell. The long term character and significance of museum displays of human remains is misinterpreted and misunderstood without recognition and engagement with how the cremated dead are deployed to articulate dimensions of the human past to visitors.

In a climate where the cremated dead have long been side-lined and regarded as secondrate evidence, this recognition might foster new, innovative approaches to the display of the cremated dead. This might be done by adopting some of the innovative attempts to speak about other dimensions of mortuary variability, process, and change identified in the museum displays of the cremated dead discussed in this chapter, as well as recognizing existing lacunae in current curatorial practice.

There are broader implications still for how we think about displaying human remains as a cultural practice (Nilsson Stutz this volume) as well as its relationship to contemporary dialogues with the dead using ashes and urns. The contemporary archaeological study of cremation needs to engage criticallywith the display of cremation in the modern museum alongside its investigations of cremation memorials and landscapes in the contemporary world (e.g. Williams 2011). Recognizing the way we deal with cremation sheds light on our own attitudes and practices surrounding the cremated remains of the dead. The ubiquity of displays involving cremation, and the diversity inherent within them, speaks volumes regarding Western attempts to employ cremation anew in the late twentieth-and early twenty-first centuries. Exploring cremation in the museum as more than an issue of curatorial practice but relating to broader debates in public mortuary archaeology and contemporary mortuary archaeology will ensure that cremated human remains continue to fire the imagination about the past and present. 


\section{ACKNOWLEDGEMENTS}

I am grateful for the feedback from the audiences of earlier versions of this paper at the following venues: Cardiff Osteoarchaeology Research Group Conference, 9-10 October 2009, the Institute for Archaeologists annual conference at Southport, April 2010, and the Theoretical Archaeology Group annual conference at Bristol, December 2010. For photographic permissions, thanks to Hjemsted Oldstidsparken, Denmark; Colchester CastleMuseum, UK' Museum Sønderjylland,Haderslev, Denmark; Historiska Museet, Stockholm, Sweden and Mats Vänehem. I am also very grateful for the staff of the museums that provided the case studies for this paper. I am equally grateful to Annika Bünz, Nina and Philip Crummy, Ing-Marie Back Danielsson, Jessica Cerezo-Román, Melanie Giles, Amy Gray Jones, Mads Holst, Pernille Kruse, Anna Mackenzie, Karen Høilund Nielsen, John Robb, Martin Rundkvist, Fredrik Svanberg, Paul Sealey, Tim Flohr Sørensen, Anna Wessman, and Philip Wise for their insights and critical comments on earlier drafts of the paper. All errors and opinions remain my own.

\section{ENDNOTES}

1. http://hjemsted.dk/en (Accessed 29 June 2015).

2. http://openarchaeology.info/venues/hjemsted-oldtidsparken-dk (Accessed 29 June 2015).

3. http://www.museum-sonderjylland.dk/arkeologien.html (Accessed 29 June 2015). 4. http://www.historiska.se/home/ (Accessed 29 June 2015).

\section{BIBLIOGRAPHY}

Andersson, G. 1997. A struggle for control: reflections on the change of religion in a rural context in the Eastern Mälaren Valley, in H. Andersson, P. Carelli, and L. Ersgård (eds) Visions of the Past: Trends and Traditions in Swedish Medieval Archaeology, Lund Studies in Medieval Archaeology, 19, 353-72, Stockholm: Central Board of National Antiquities.

Andersson, G. 2005. With Thor on our side: the symbolism of the Thor hammer-ring in Viking Age burial ritual, in T. Artelius and F. Svanberg (eds) Dealing with the Dead, 45-62, Stockholm: National Heritage Board.

Andersson, G. 2006. Among trees, bones and stones: the sacred grove at Lunda, in A. Andrén, K. Jennbert, and C. Raudvere (eds) Old Norse Religion in Long-term Perspectives: Origins, Changes, and Interactions, 195-9, Lund: Nordic Academic Press. Anon. 1997. Colchester Castle Museum: A Souvenir Guide, Colchester: Colchester Borough Council.

Asingh, P. 2011. Seven Vikings, in H. Skov and J. Varberg (eds) Aros and the World of the Vikings, Aarhus: Moesgård Museum.

Back Danielsson, I.-M. 2011. Presenting the past: On archaeologists and their influence on modern burial practices, Mortality, 16(2), 98-112.

Bahn, P. (ed.) 2002. Written in Bones, Newton Abbot: David and Charles. 
Beattie, O. 1999. Sleep by the shores of those icy seas: death and resurrection in the last Franklin expedition, in J. Downes and T. Pollard (eds) The Loved Body's Corruption: Archaeological Contributions to the Study of Human Mortality, 19-29, Glasgow: Cruithne.

Bünz, A. 2012. Is it enough to make the main characters female? An intersectional and social semiotic reading of the exhibition Prehistories 1 at the National Historical Museum in Stockholm, Sweden, in I.-M. Back Danielsson and S. Thedéen (eds) To Tender Gender: The Pasts and Futures of Gender Research in Archaeology, 97-116, mStockholm: University of Stockholm.

Brooks, M. M. and Rumsey, C. 2007. The body in the museum, in V. Cassman, N. Odegaard, and J. Powell (eds) Human Remains: Guide for Museum and Academic Institutions, 261-89, London: Altamira.

Browne, T. 1658. Hydriotaphia, Urne-Buriall, or a Discourse on the Sepulchrall Urnes lately found in Norfolk, London: Ivy-lane.

Chamberlain, A. and Parker Pearson, M. 2001. Earthly Remains: The History and Science of Preserved Human Bodies, London: British Museum.

Cougill, W. 2006. Buddhist cremation traditions for the dead and the need to preserve forensic evidence in Cambodia, in J. Lohman and K. Goodnow (eds) Human Remains and Museum Practice, 75-9, London: Museum of London.

Curtis, N. G. W. 2003. Human remains: The sacred, museums and archaeology, Public Archaeology, 3, 21-32.

Crossland, Z. 2009a. Of clues and signs: the dead body and its evidential traces, American Anthropologist, 111(1), 69-80.

Crossland, Z. 200gb. Acts of estrangement. The post-mortem making of self and other, Archaeological Dialogues, 16(1), 102-25.

Crummy, P. 1997. City of Victory: The Story of Colchester-Britain's First Roman Town, Colchester: Colchester Archaeological Trust.

Ethelberg, P. 1986. Hjemsted-en graveplads fra 4.og 5. årh. e. Kr. Haderslev: Skrifter fra Museumsrådet for Sønderjyllands Amt, 2.

Ethelberg, P. 1990. Hejmsted 2-tre gravepladser fra 3. og 4. årh. e. Kr. Haderslev: Skrifter fra Museumsrådet for Sønderjyllands Amt, 3.

Giesen, M. (ed.) 2013. Curating Human Remains: Caring for the Dead in the United Kingdom, Woodbridge: Boydell Press. 
Goodnow, K. 2006a. Why and when do human remains matter: museum dilemmas, in J. Lohman and K. Goodnow (eds) Human Remains and Museum Practice, 16-20, London: Museum of London.

Goodnow, K. 2006b. Bodies: taking account of viewers' perspectives, in J. Lohman and K. Goodnow (eds) Human Remains and Museum Practice, 123-30, London: Museum of London.

Giles, M. 2009. Iron Age bog bodies of north-western Europe. Representing the dead, Archaeological Dialogues, 16(1), 75-101.

Gräslund, A.-S. 1981. Birka IV: The Burial Customs. A study of the graves on Björkö, Stockholm: Almqvist and Wiksell International.

Hall, M. 2013. The quick and the deid: a Scottish perspective on caring for human remains at the Perth Museum and Art Gallery, in M. Giesen (ed.) Curating Human Remains: Caring for the Dead in the United Kingdom, 75-86, Woodbridge: Boydell Press.

Høilund Nielsen, K. 2009. Rituals to free the spirit-or what the cremation pyre told, in D. Sayer and H. Williams (eds) Mortuary Practices and Social Identities in the Middle Ages: Essays in Burial Archaeology in Honour of Heinrich Härke, 104-22, Exeter: University of Exeter Press.

Hope, V. 1997a. A roof over the dead: communal tombs and family structure, in R. Laurence and A. Wallace-Hadrill (eds) Domestic Space in the Roman World, 69-88, Portsmouth: Journal of Roman Archaeological Supplementary Series No. 2.

Hope, V. M. 1997b. Words and pictures: the interpretation of Romano-British tombstones, Britannia, 27, 245-58.

Jenkins, T. 2010. Contesting Human Remains in Museums: The Crisis of Cultural Authority, London: Routledge.

Nordström, N. 2007. De odöldliga. Förhistoriska individer i vetenskap och media, Falun: Nordic Academic Press.

Nørgård Jørgensen, A. 2011. Mission impossible: the Ejsbøl army. Organisation, attack and defeat, in L. Boye, L. Heidemann Lutz, S. Kleingärtner, P. Kruse, L. Matthes, and A. B. Sørensen (eds) Arkæologi i Slesvig/Archäologie in Schleswig. Sonderband 'Det 61. Internationale Sachsensymposion 2010': Haderlsev, Denmark, 297-316, Neumünster: Wachholtz.

Parker Pearson, M. 1999. The Archaeology of Death and Burial, Stroud: Sutton.

Parker Pearson, M., Pitts, M., and Sayer, D. 2013. Changes in policy for excavating human remains in England and Wales, in M. Giesen (ed.) Curating Human Remains: Caring for the Dead in the United Kingdom, 147-58, Woodbridge: Boydell Press. 
Redfern, R. and Bekvalac, J. 2013. The Museum of London: an overview of policies and practice, in M. Giesen (ed.) Curating Human Remains: Caring for the Dead in the United Kingdom, 87-98, Woodbridge: Boydell Press.

Sanders, K. 2009. Bodies in the Bog and the Archaeological Imagination, Chicago: University of Chicago Press.

Sayer, D. 2010. Ethics and Burial Archaeology, London: Duckworth.

Svanberg, F. 2003. Death Rituals in South-East Scandinavia AD 800-1000: Decolonizing the Viking Age 2, Lund: Acta Archaeologica Lundensia Series in 4ㅇ 24.

Swain, H. 2002, The ethics of displaying human remains from British archaeological sites, Public Archaeology, 2, 95-100.

Swain, H. 2006. Public reaction to the displaying of human remains at the Museum of London, in J. Lohman and K. Goodnow (eds) Human Remains and Museum Practice, 97-105, London: Museum of London.

Swain, H. 2007a. An Introduction to Museum Archaeology, Cambridge: Cambridge University Press.

Swain, H. 2007b. The value of human remains in museum collections, Public Archaeology, 6(3), 193-7.

Wallace, J. 2005. Digging the Dirt: The Archaeological Imagination, London: Duckworth.

Werner, A. 1998. London Bodies, London: Museum of London.

Williams, H. 2008. Towards an archaeology of cremation, in C. W. Schmidt and S. Symes (eds) The Analysis of Burned Human Remains, 239-69, London: Academic Press.

Williams, H. 2009. On display: envisioning the early Anglo-Saxon dead, in D. Sayer and $\mathrm{H}$. Williams (eds) Mortuary Practices and Social Identities in the Middle Ages: Essays in Burial Archaeology in Honour of Heinrich Härke, 170-206, Exeter: University of Exeter Press.

Williams, H. 2011. Cremation and present pasts: a contemporary archaeology of Swedish memory groves, Mortality, 16(2), 113-30. 